\title{
SIZES AND DISTRIBUTIONS OF INTRINSIC NEURONS INCORPORATING TRITIATED GABA IN MONKEY SENSORY-MOTOR CORTEX ${ }^{1}$
}

\author{
S. H. C. HENDRY AND E. G. JONES
}

Department of Anatomy and Neurobiology, Washington University School of Medicine, St. Louis, Missouri 63110

\begin{abstract}
Neurons accumulating $\left[{ }^{3} \mathrm{H}\right] \gamma$-aminobutyric acid (GABA) were identified autoradiographically in frozen and plastic sections after injection of the material in the monkey somatic sensory (areas 3,1 , and 2), motor (area 4), and parietal (area 5) cortex following intravenous administration of a GABA transaminase inhibitor, amino-oxyacetic acid. Two general forms of labeled cells are recognized: those with large diameter (15- to $20-\mu \mathrm{m}$ ) somata, probably corresponding to the basket cells of Golgi studies, and those with small diameter (6- to $12-\mu \mathrm{m})$ somata, probably corresponding to several other types. The sizes and laminar distributions of labeled cells in the cytoarchitectonic fields of the first somatic sensory area (SI) are similar. In these areas, the greatest concentrations of labeled cells are in layer II, in layer IV, and in the superficial stratum of layer VI. In area 5 , there are many fewer labeled cells in layer IV. In area 4, the labeled cells are larger and distributed more homogeneously, though there are fewer in layer VI. The large labeled cell type is concentrated in layers III and V of all areas. The smaller labeled types are found in all other layers, including layer I. In layer IV, they form approximately $40 \%$ of the total small-celled neuronal population.
\end{abstract}

The accumulated evidence of more than a decade of neuropharmacological research has led to the realization that $\gamma$-aminobutyric acid (GABA) is a major constituent of many parts of the central nervous system. And few would doubt that it functions as an inhibitory neurotransmitter agent (Krnjevíc, 1974). The mammalian neocortex is one of several regions in which the functional role of GABA has been studied intensively (Krnjevic and Phillis, 1963; Crawford and Curtis, 1964; Krnjevíc and Schwartz, 1967; Dreifuss et al., 1969; Iversen et al., 1971; Emson and Lindvall, 1979; Dichter, 1980). Potentially, at least, GABA may be one of the major inhibitory transmitters of the neocortex and already it has been suggested that it determines many of the receptive field properties of visual cortical neurons in normal animals (Sillito, 1975, 1977a, b, 1979; Sillito and Versiani, 1977; Tsumoto et al., 1979) and in animals subjected to sensory deprivation (Duffy et al., 1976). Though no comparable effects of GABA have been demonstrated in other cortical areas, postsynaptic inhibitory phenomena have been described frequently in certain of the sensory areas. In addition to playing a powerful role in the shaping of receptive field properties, intracortical inhibition has been regarded often as one of the prime agents in molding the columnar

\footnotetext{
${ }^{1}$ This work was supported by Grant NS10526 from the Nationa Institutes of Health, Inited States Public Health Service. We thank Bertha McClure and Ronald Steiner for excellent technical assistance.
}

properties upon which the processing of sensory information in these areas of cortex depends (Mountcastle and Powell, 1959; Hubel and Wiesel, 1965; Jones, 1980).

Afferent fibers entering the sensory areas of the cortex from the appropriate thalamic nuclei appear to exert an excitatory effect upon the recipient neurons, but activation by thalamic fibers is followed often by disynaptic inhibitory effects (Toyama et al., 1974; Watanabe et al., 1966; Stefanis, 1969; Stone, 1973). This usually has been attributed to local interneurons rather than to the collaterals of the efferent, pyramidal cell axons. Thereforc, it may be expected that GABA-mediated and other forms of intracortical inhibition are functions of some of the large population of non-pyramidal neurons whose axons do not leave the cortex (hereafter called intrinsic neurons). In the somatic sensory and motor cortex of the monkey, it has been possible to identify with the Golgi technique (Jones, 1975) seven broad classes of intrinsic neuron, each with a stereotyped axonal ramification that is unique to that class (see also Feldman and Peters, 1978 , for a similar study on the rat). Certain of the cell classes also have characteristic somal diameters and laminar distributions. Some of these classes of intrinsic neurons have been fitted into hypothetical circuit diagrams that could account for aspects of the electrophysiological phenomena demonstrable in the somatic sensory cortex (Jones, 1980). The morphological features of the synapses made by what are probably the equivalents of some of 
these classes of intrinsic cell are becoming known in nonprimates (Peters and Feldman, 1976; Somogyi, 1977). In the rat visual cortex (Ribak, 1978), electron microscopic profiles typical of some have been found to contain the GABA-synthesizing enzyme, glutamic acid decarboxylase, but still very little is known about the synaptic characteristics of the intrinsic cells.

Two methods are currently available for attempting to define the classes of intrinsic cortical neurons that synthesize GABA. The first, which was used very successfully by Ribak (1978) in the rat visual cortex, involves the immunocytochemical localization of glutamic acid decarboxylase. The other makes use of the high affinity uptake system that neurons utilizing GABA as a transmitter are known to possess for that substance (Neal and
Iversen, 1969). Such cells thus concentrate radioactive GABA injected into the brain and may be localized autoradiographically. We have chosen this method because we felt it might give a rather higher yield of labeled cells for quantitative analysis. The yield and intensity of labeling have been enhanced further by the use of the GABA transaminase inhibitor, amino-oxyacetic acid (Wallach, 1961; Halasz et al., 1979).

Others who have used the autoradiographic procedure in the rat have remarked upon the labeling of putatively GABAergic cells in the cortex (Hökfelt and Ljungdahl, 1972; Chronwall and Wolff, 1978, 1980), but little attempt has been made to correlate the labeled cells with morphological types of intrinsic neurons and no quantitative studies of differences in laminar and cytoarchitectonic

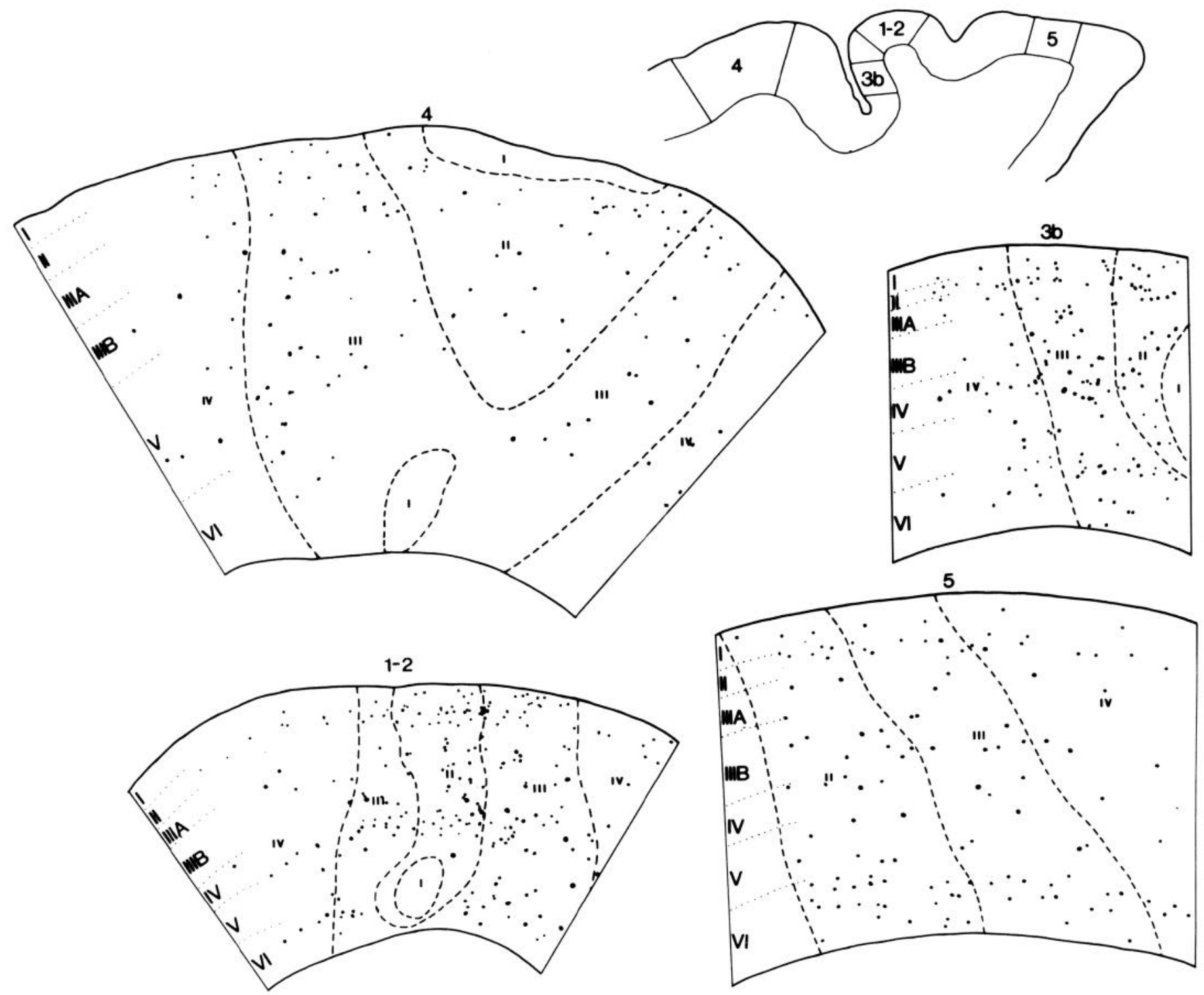

Figure 1. Camera lucida drawings from the parts of areas 4, 3b, 1-2, and 5 indicated on the drawing of a sagittal section through the central sulcus showing the four arbitrary zones ( $I$ to $I V$ ) of labeling around an injection site and the laminar distribution of labeled neurons. Each drawing is to one side of the central core of the injection. Note concentrations of labeled neurons in layers $I I, I I I B, I V, V$, and $V I$. 

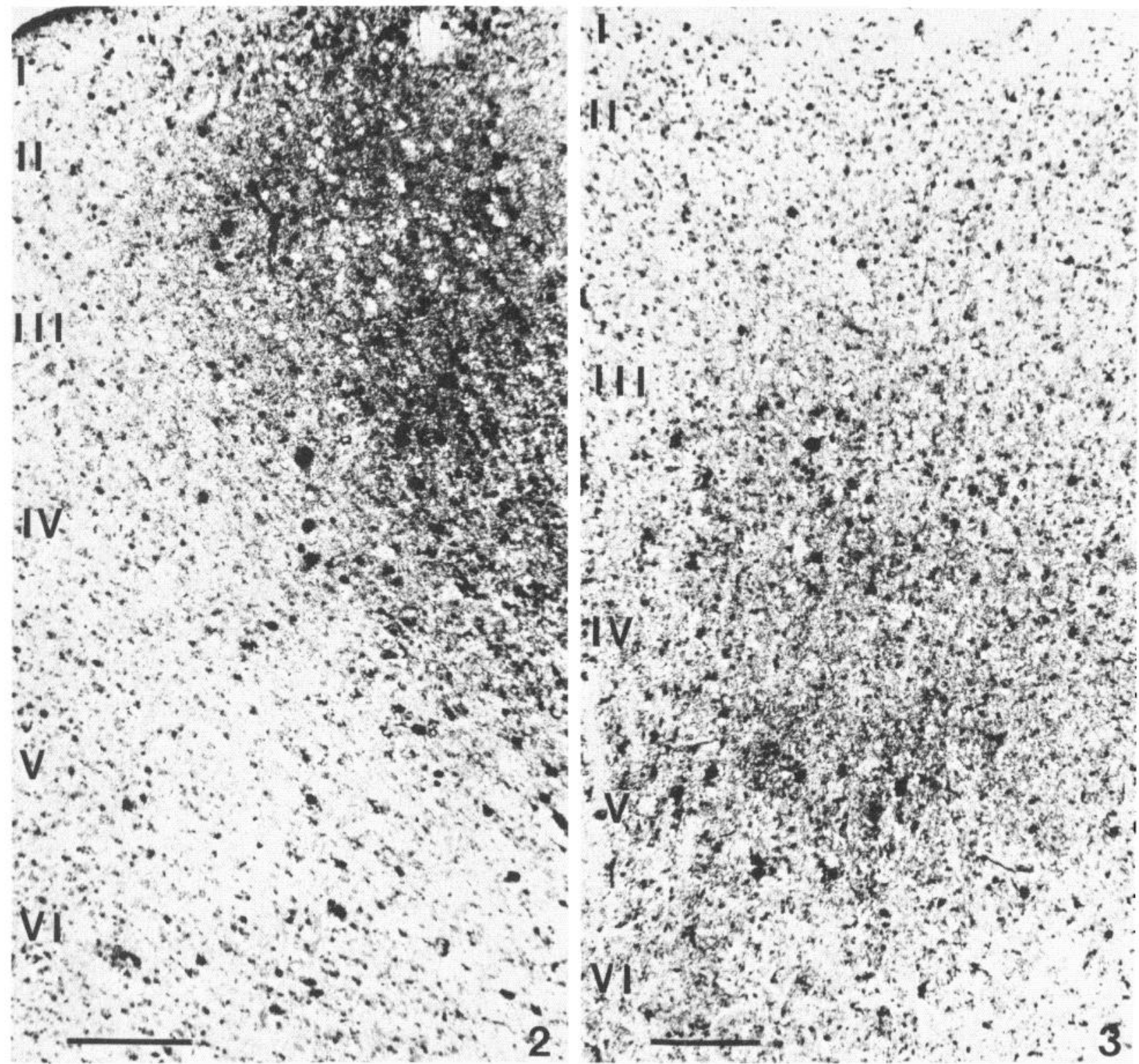

Figure 2 (left). Photomicrograph from the first somatic sensory area (SI) at the edge of a site of injection of [ $\left.{ }^{3} \mathrm{H}\right] \mathrm{GABA}$. Unlabeled but counterstained cells have been largely eliminated by underexposure of the photographic print. Note concentrations of large GABA-labeled cells in layers $I I I$ and $V$, the clear spaces at the center of the injection site that indicate unlabeled neurons, and the scattered labeled cells in all layers beyond the injection site. Counts and measurements were made approximately in a zone corresponding to the middle of the photomicrograph and from a comparable region in semi-thin plastic sections. Bar represents $200 \mu \mathrm{m}$.

Figure 3 (right). Higher magnification photomicrograph showing particularly the concentrations of large GABA-labeled neurons in layers $I I I B$ and $V$, the moderate concentration of small labeled neurons in layer $I V$, and scattered labeled neurons in other layers. Bar represents $200 \mu \mathrm{m}$.

field distribution have been reported. A preliminary account of these findings has appeared (Hendry and Jones, 1980 ).

\section{Materials and Methods}

Five cerebral hemispheres from three cynomolgus monkeys (Macaca fascicularis) were used in this study. Each animal was deeply anesthetized with Nembutal and, $30 \mathrm{~min}$ prior to opening the skull, was given an intravenous injection of the GABA transaminase inhibitor, amino-oxyacetic acid $(40 \mathrm{mg} / \mathrm{kg}$ of body weight).
Thereafter, $\left[{ }^{3} \mathrm{H}\right] \mathrm{GABA}$ (specific activity, $40.2 \mathrm{Ci} / \mathrm{mmol}$ ) was injected through a $10-\mu \mathrm{l}$ Hamilton syringe at multiple sites in the pre- and postcentral gyri and superior parietal lobule. The $\left[{ }^{3} \mathrm{H}\right] \mathrm{GABA}$ was evaporated and reconstituted in normal saline to give a final activity of 20 or $50 \mu \mathrm{Ci} /$ $\mu \mathrm{l}$ and between 0.5 and $1.0 \mu \mathrm{l}$ were injected at three or more sites. Twenty minutes following the final injection and a maximum of $80 \mathrm{~min}$ after the first, blocks of cortex containing the injection sites were removed surgically, washed briefly in normal saline, and immersed in a cold solution of $3.5 \%$ glutaraldehyde and $1 \%$ paraformaldehyde in $0.1 \mathrm{~m}$ phosphate buffer, $\mathrm{pH}$ 7.2. As a control, 3 
$\mu \mathrm{l}$ of a $50 \mu \mathrm{Ci} / \mu \mathrm{l}$ solution of $\left[{ }^{3} \mathrm{H}\right]$ leucine (specific activity, $47 \mathrm{Ci} / \mathrm{mmol}$ ) in normal saline was injected over the same time as the injections of $\left[{ }^{3} \mathrm{H}\right] \mathrm{GABA}$ and the brain injected with this material was treated subsequently in the same way.

After 4 or 5 days in the fixative, the blocks were processed in one of two ways. Blocks from three hemispheres were immersed in $30 \%$ sucrose in phosphate buffer until they sank. They then were cut as $20-\mu \mathrm{m}$ thick frozen sections and mounted on gelatinized slides. Blocks from two hemispheres were sectioned at $100 \mu \mathrm{m}$ on a Vibratome and small pieces of the sections, at various proximities to the needle tracks, were cut out with a razor blade, postfixed in $2 \%$ osmium tetroxide, dehydrated in ethanol, and embedded in Spurr's resin.
Serial $1-\mu \mathrm{m}$-thick sections were cut with glass knives and were mounted by heating onto slides. Both the frozen and the plastic sections were coated with Kodak NTB2 emulsion and exposed at $4^{\circ} \mathrm{C}$ for $2,4,8$, or 12 weeks. The sections then were developed in Kodak D19, fixed, and stained through the emulsion either with thionin for the frozen sections or with methylene blue and azure II for the plastic sections.

When examining the $20-\mu \mathrm{m}$-thick sections, it was convenient to divide the sections into four zones in relation to an injection site (Fig. 1). All injections used for analysis, at their center, extended from pia to white matter. The four zones are similar to those used by Chronwall and Wolff (1980). Zone I includes any tissue destroyed by the needle track and the densest part of the injection
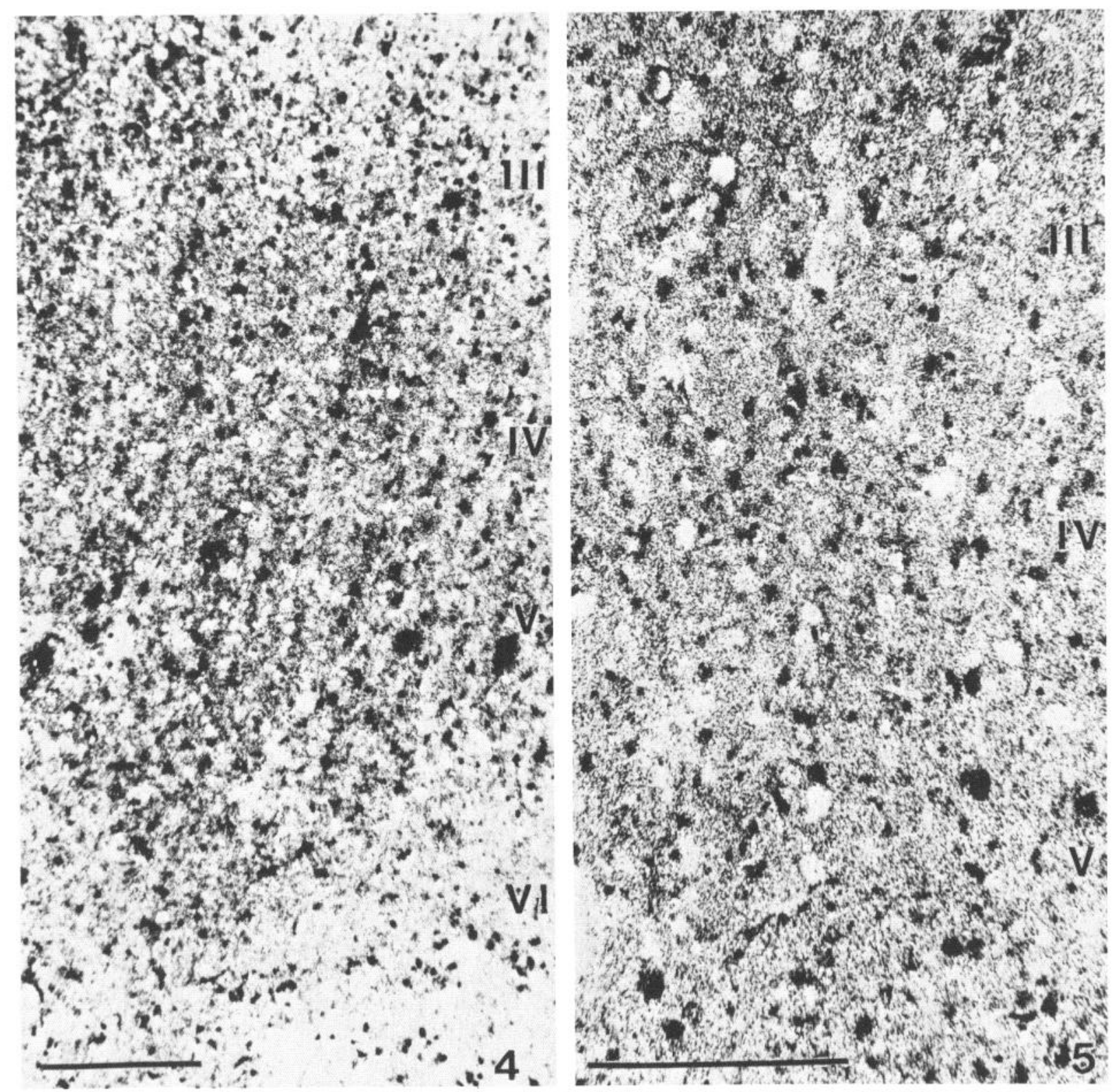

Figure 4 (left). Photomicrograph showing the concentration of GABA-labeled cells in the superficial part of layer VI in area $3 \mathrm{~b}$. Bar represents $200 \mu \mathrm{m}$.

Figure 5 (right). Photomicrograph from areas 1-2 showing the clear spaces that indicate unlabeled cells in layers III to V. Note that many of the unlabeled cells have a clear pyramidal shape. Bar represents $200 \mu \mathrm{m}$. 

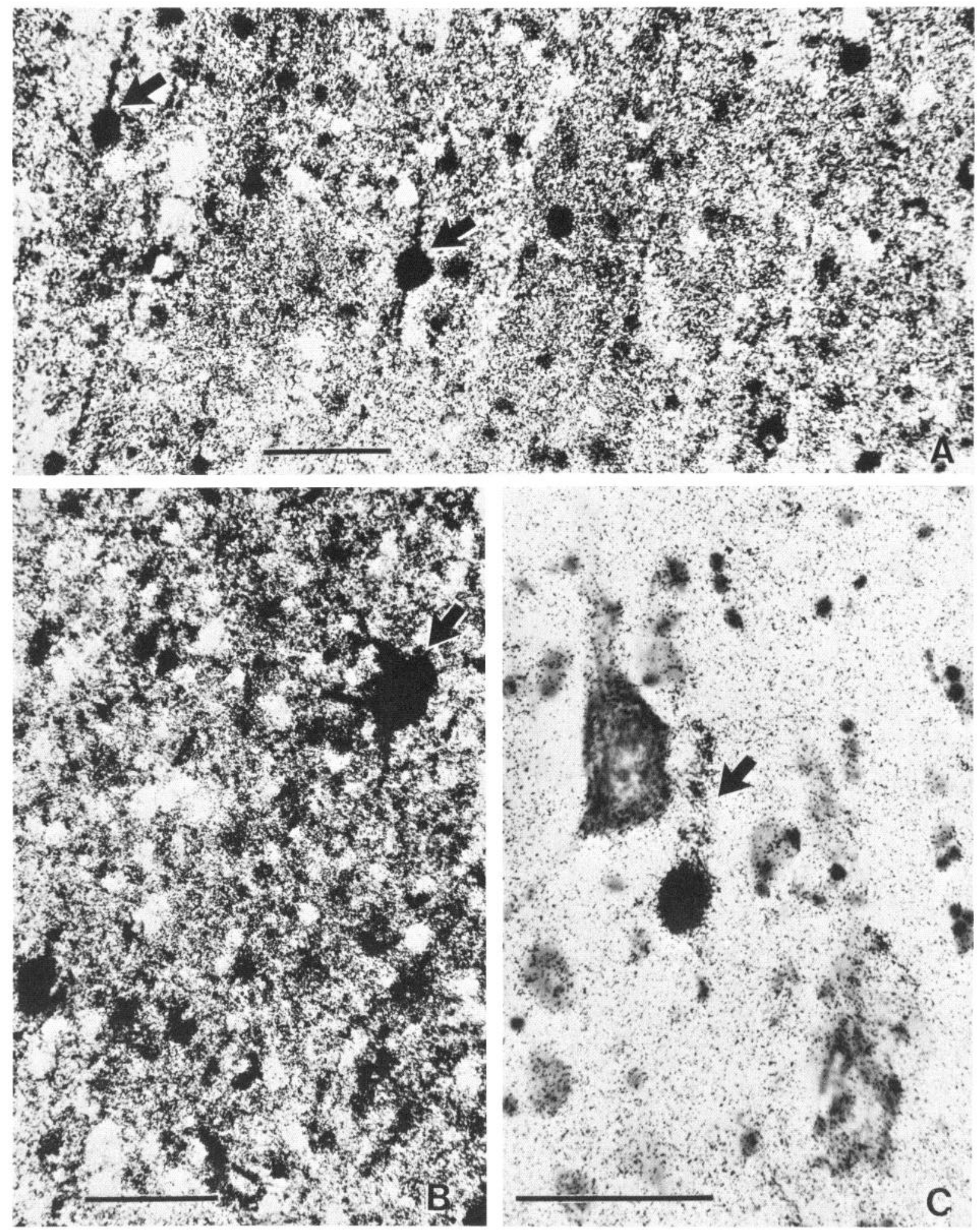

Figure 6. $A$ to $C$, Photomicrographs showing the labeling of cell processes (arrows) in $20-\mu$ m-thick frozen sections. In $A$, from layer III of area 5 , several fusiform or multipolar types are seen. In $B$, a large cell from layer IIIB of area $3 \mathrm{~b}$ has a clear multipolar form. In $C$, a labeled probable fusiform cell lies beside an unlabeled giant pyramidal cell in layer V of area 4 . Bars represent 50 $\mu \mathrm{m}$.

site which is covered by a concentration of silver grains so heavy as to make resolution of individual cells extremely difficult. Zone II is made up of the immediately adjacent region, 200 to $500 \mu \mathrm{m}$ in width, of still very heavy labeling, in which many heavily labeled cells can be discerned amid the neuropil labeling. Flanking zone II is the relatively narrow $(200-$ to $300-\mu \mathrm{m})$ zone III of greatly diminished background labeling but populated by many heavily labeled cells (Figs. 1 and 2). Outside this zone, in zone IV, background labeling falls to a rather 
steady and comparatively low level. In zone IV, fewer labeled cells are found and, though the labeling of the somata far exceeds that of the neuropil and of the background, the density of grains overlying the somata is much less than that found in zones II and III. Background levels of labeling were assessed by examination of parts of the section containing parts of the cortex that are far removed from the injection site.

For the purposes of quantitative analysis, only cells located in zone III of cytoarchitectonic areas $3 \mathrm{~b}, 1,2,4$, and 5 were examined. No attempt was made to distinguish between areas 1 and 2 which are hereafter referred to as "areas 1-2." To determine the laminar distribution of cells accumulating $\left[{ }^{3} \mathrm{H}\right] \mathrm{GABA}$, the outlines of labeled cell somata encountered on a vertical traverse $430 \mu \mathrm{m}$ wide through the thickness of the cortex were drawn with a camera lucida from single $1-\mu \mathrm{m}$-thick plastic and 20 $\mu$ m-thick frozen sections representative of each of the areas except area 5 . No plastic sections were available from area 5. Laminar borders were determined from the thionin counterstaining and were marked onto the drawing though this is less accurate in the semi-thin sections. The total depth of the traverse was then divided into sequential $60-\mu \mathrm{m}$ steps. The number of labeled cells in each of the $430 \times 60 \mu \mathrm{m}$ rectangles of cortical tissue was then plotted onto a bar graph. The $20-\mu \mathrm{m}$-thick frozen sections were used because the desired degree of uniformity in the injection site and the four zones mentioned above were observable only in these thicker sections, and one could be more confident about borders of cortical laminae. However, the density of labeling of individual cells was high in the frozen section autoradiographs, often obscuring the underlying cell. Therefore, to distinguish neurons from glial cells and to ensure that fragments of cells were not being counted as whole cells, parallel counts were made from single $1-\mu \mathrm{m}$-thick plastic section autoradiographs. The positions of the plastic sections relative to zone III were estimated from frozen section autoradiographs of the Vibratome slices from which their parent blocks were taken. In the semi-thin autoradiographs, only labeled neurons in which a distinct nucleolus could be observed (e.g., Fig. 7) were measured. The density of labeling of neurons (e.g., Fig. 8) was somewhat variable so that some degree of observer selection was involved, usually by excluding the more lightly labeled neurons.

For size analysis, the perimeters of labeled cells in zone III were drawn at a final magnification of $\times 500$. All of the labeled cells in a thick or semi-thin section were drawn until at least 50 cells from each layer, except layer
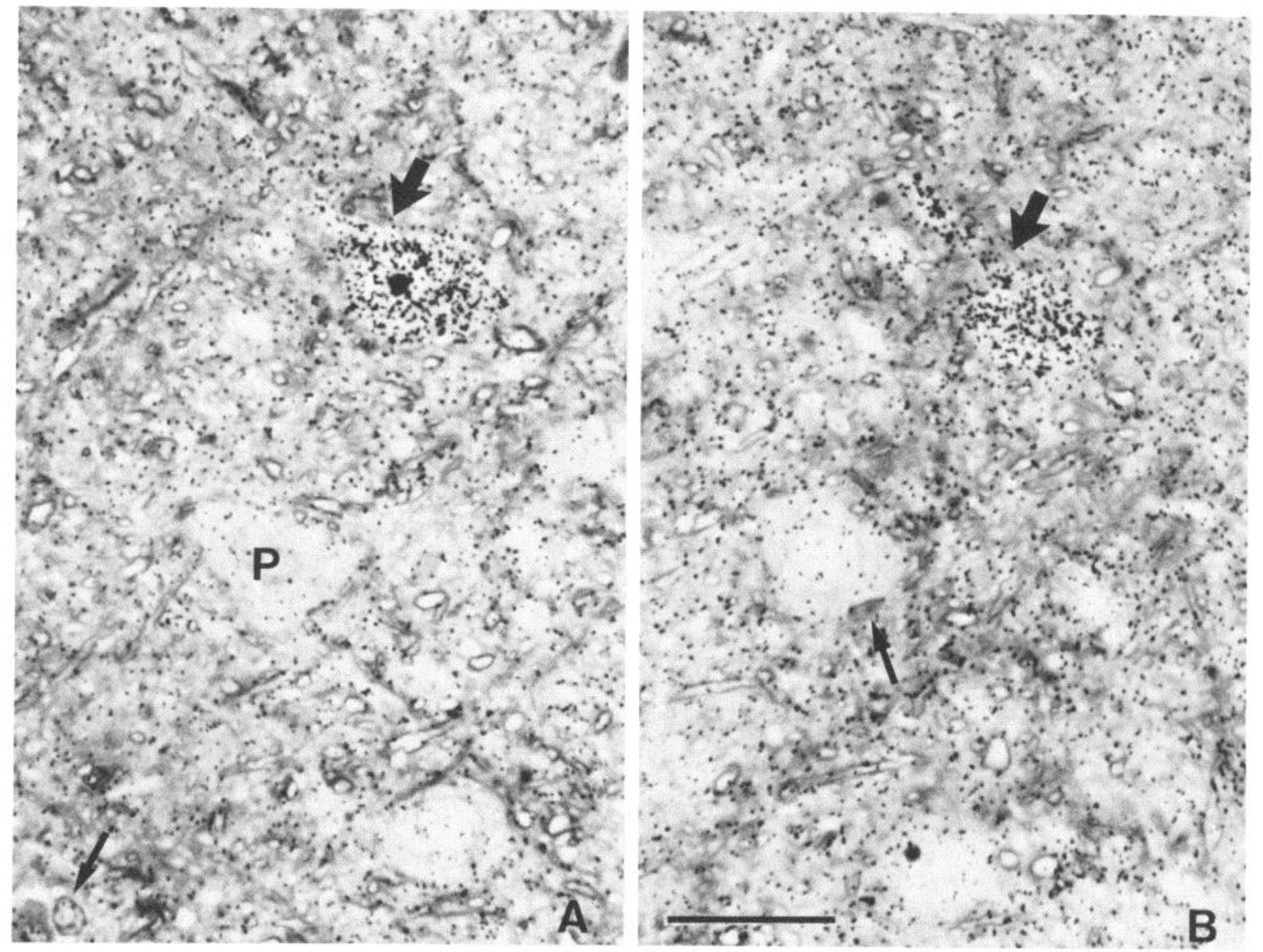

Figure 7. $A$ and $B$, Photomicrographs from adjacent $1-\mu \mathrm{m}$-thick plastic sections showing selective GABA labeling of a large cell in layer $\mathrm{V}$ of area $3 \mathrm{~b}$. Note labeling of its processes (large arrows) and the lack of labeling of adjacent pyramidal cells $(P)$ and glial cells (small arrows). The surface of the brain is toward the lower left. Bar represents $25 \mu \mathrm{m}$. 
I of each cytoarchitectonic area, were obtained. Then, using a computer pantograph (Cowan and Wann, 1973), the perimeters were measured and the measurements were converted into diameters for circular profiles having the same perimeters as the measured cells. These are strictly "equivalent diameters" but will be referred to simply as "diameters" in the remainder of the text (Figs. 9 to 16$)$.

To compare the sizes of labeled cells with those of all cells in an area, a part of each cytoarchitectonic field outside zone IV of the injection was chosen and all the stained neurons in each layer were drawn and measured in a 430- $\mu \mathrm{m}$-wide traverse as for labeled cells. Analysis of the sizes of labeled and of all cells was done graphically for each field as a whole and independently for layer IV in each field. Cells were grouped according to their diameters into bins of $1.5 \mu \mathrm{m}$ beginning with $6.0 \mu \mathrm{m}$. Labeled cells with diameters smaller than $6.0 \mu \mathrm{m}$ in the plastic section autoradiographs were found to be almost exclusively glial cells. The percentage of the labeled or total population that each bin made up was computed, and the bin was plotted against that percentage (Figs. 11, 14 , and 16).

\section{Results}

Qualitative. The four arbitrary zones in and around the injection site and from which one was chosen for quantitative analysis have been mentioned already. Certain general features, many of which are confirmed by the quantitative data, also warrant mention. At the central core of the injection (zone I), the tissue is uniformly blackened by overlying silver grains. There is little variation in grain density over cells and neuropil and all classes of neurons, including obvious pyramidal cells, as well as neuroglial cells, are heavily labeled. Entering the white matter beneath the injection core, a number of heavily labeled axons are visible. These cannot be traced for more than 2 to $3 \mathrm{~mm}$ at the short survival times used. The uniform labeling at the central core of the injection and the labeling of efferent axons does not differ significantly in the brain in which $\left[{ }^{3} \mathrm{H}\right]$ leucine was injected.

Around zone I, in zones II and III, heavy labeling of individual cells becomes obvious, especially in zone III in which there is a substantial reduction in neuropil labeling (Figs. 1 and 2). Scattered among the labeled cells in both zones are the overt somata of pyramidal cells which, though labeled heavier than background, are less densely labeled than the neuropil and far less densely labeled than those that we regard as having concentrated $\left[{ }^{3} \mathrm{H}\right]-$ GABA. The unlabeled somata, especially in zone II where the neuropil labeling is heaviest, form a series of unlabeled spaces giving an appearance resembling vacuolation of the tissue (Figs. 2 and 5). In the small-celled layer IV, there is also a substantial population of small round somata also labeled less densely than the neuropil and approximately equal in number to the labeled somata in this layer (Fig. 3). Glial cell labeling is generally, though not universally, heavier than neuropil labeling in zone II and lighter than neuropil labeling in zone III. In zone III, as assessed from semi-thin sections (Fig. 8), many astrocytes and oligodendrocytes are clearly unlabeled. No labeled axons enter the white matter from zones II to IV, and the pattern of somal and neuropil labeling is not seen in the control experiment with an injection of $\left[{ }^{3} \mathrm{H}\right] l e u-$ cine.

In zones II and III, two distinct categories of labeled somata are visible: large (approximately 15 to $25 \mu \mathrm{m}$ in diameter) and small (approximately 6 to $12 \mu \mathrm{m}$ in diameter) (Figs. 2 to 4 ). The large labeled somata are oval or angular and do not differ greatly in size from the somata of the larger pyramidal cells (Fig. 7). They are confined - almost totally to layers IIIB and V. Commonly, thick dendrites emanating from these cells are labeled for up to $200 \mu \mathrm{m}$ (Fig. 6) away from the parent somata. Where more than one dendrite can be traced, the large labeled cell can be identified, tentatively, as multipolar in form.

The smaller labeled somata in zones II and III are round or oval and are found in all layers, including a few in layer I (Figs. 2, 3, and 8). Some variation in size is visible, but, apart from a relative paucity of numbers in layer VI, no laminar variations are distinguishable at the qualitative level. Small clusters of labeled somata are

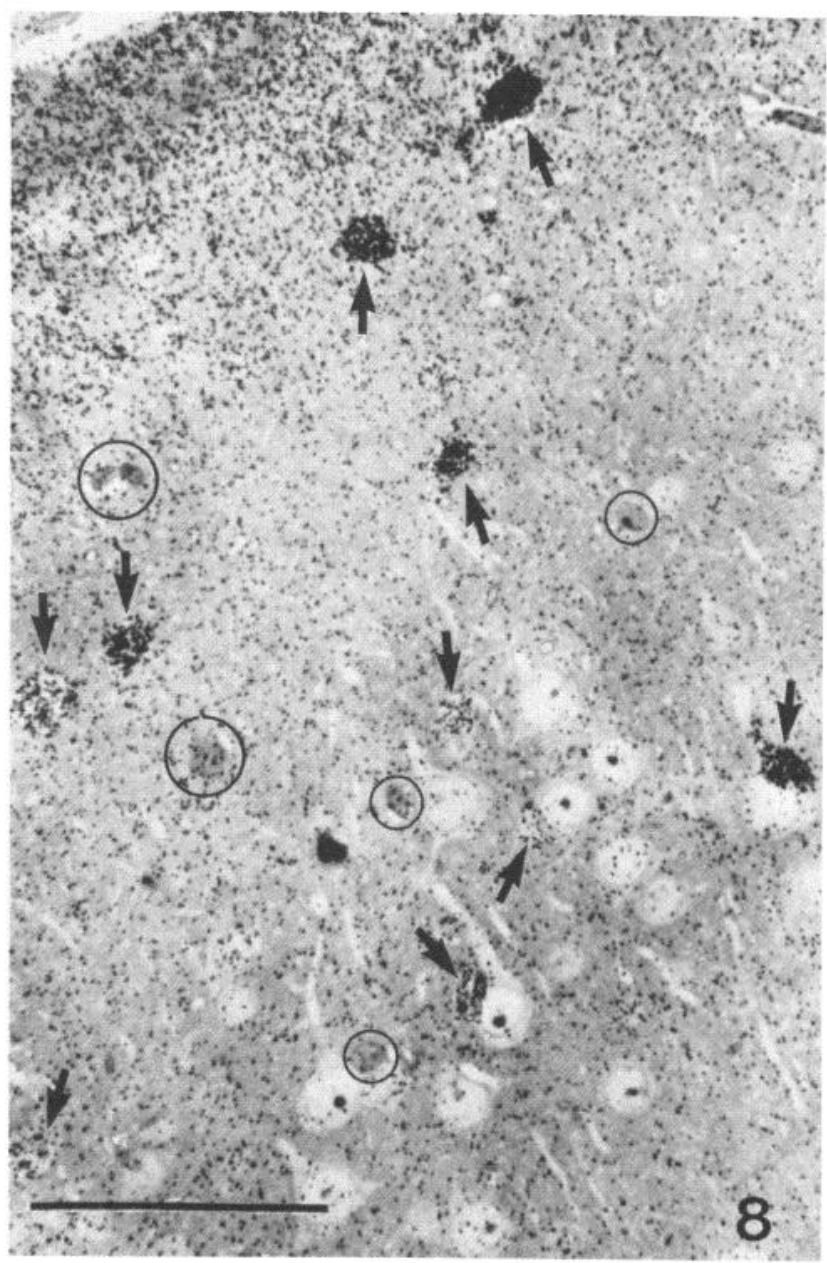

Figure 8 . Photomicrograph from a $1-\mu \mathrm{m}$-thick plastic section showing selective GABA labeling of neuronal somata in layers I and II of areas 1-2. Glial cell somata (ringed) are smaller than those of the labeled cells and are mostly unlabeled. Neurons show variable density of labeling (arrows). Note the concentration of apparently nonspecific labeling beneath the pial surface. Bar represents $100 \mu \mathrm{m}$. 
found at times in layers I and III. In zone III, as assessed from the semi-thin section autoradiographs, the labeled small somata are generally larger than those of the unlabeled or very lightly labeled neuroglial cells (Fig. 8).

A particularly clear-cut distinction can be made between labeled and unlabeled cell somata in zone IV even though the labeling of individual somata is lighter than in zones I to III. In zone IV, the two sizes of labeled somata are visible and labeled dendrites attached to the larger type often can be traced through a number of serial 1- $\mu \mathrm{m}$-thick sections (Fig. 7). The extent of labeled somata beyond the injection site is frequently greatest in layers I and VI, though some labeling in layer I can be attributed to spread of the injected material across a sulcus, such as the central. The labeled cell somata in layer I are consistently larger than the adjacent unlabeled somata of glial cells. They are interpreted, therefore, as the somata of neurons though, sometimes, even in semithin sections, the labeling is sufficiently heavy to obscure the underlying morphology. They are found in both the superficial and deep parts of the layer. Layer I of zone IV is also characterized by the presence of labeling that is not restricted to somata but which cannot be localized confidently to axons or other processes. It takes the form of a band spreading out from the injection site for several millimeters in the superficial one-third of layer I (Fig. 8). The border between this labeled zone and the rest of layer I is quite sharp and frequently is associated with a row of labeled neuronal somata.

A similar greater lateral extent of neuronal somal labeling was, at times, observed in layer VI, particularly in the postcentral gyrus. When present, it was associated with a zone of non-somal labeling in the superficial half of the layer. However, neither was a consistent finding, and we are uncertain whether it simply indicated preferential diffusion of the isotope.

Quantitative. Many of the qualitative observations made above are supported by our quantitative data made

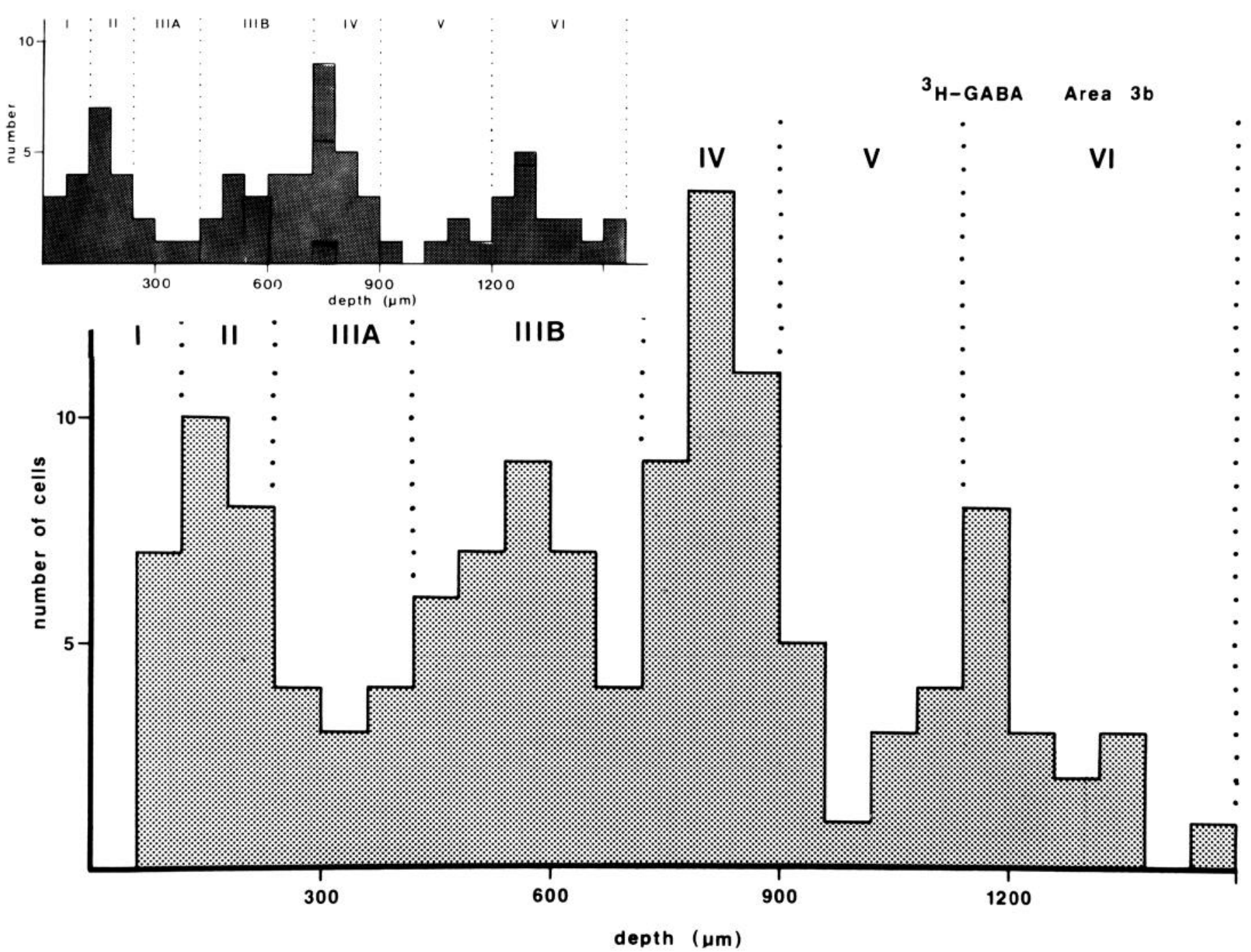

Figure 9. Distribution of labeled neuronal somata in relation to depth in a $430-\mu \mathrm{m}$-wide traverse through the cortex of area $3 \mathrm{~b}$. Note concentrations of labeled somata in layers $I I, I I I B, I V, V$, and the superficial part of layer VI. In this and subsequent figures, the lower larger graph illustrates data from single frozen section autoradiographs and the upper smaller graph illustrates data from single $1-\mu \mathrm{m}$-thick plastic section autoradiographs in which only labeled neurons with observed nucleoli were measured. 
from counts and measurements on both semi-thin and thick section autoradiographs. From these data, certain other conclusions regarding differences in distribution of labeled somata among the several cytoarchitectonic fields can be drawn.

First somatic sensory area (SI). The three cytoarchitectonic fields of SI (areas 3, 1, and 2) have essentially the same pattern of cell labeling (Figs. 9 to 12). Labeled cells in SI are not distributed homogeneously through the thickness of the cortex but are clustered at three depths. These depths correspond to layer II (often including the deep part of layer I and the superficial part of layer III), to layer IV, and to the superficial part of layer VI (Figs. 9 and 10). The presence of large numbers of $\left[{ }^{3} \mathrm{H}\right] \mathrm{GABA}$-accumulating cells in these layers is apparent both close to (zones II and III) and at a distance from (zone IV) the injection site, though only data from zone III are presented.

There is a relative paucity of cells in layer $\mathrm{V}$ and in the deep part of layer VI. The similarity in the distribution of labeled somata in the different fields of SI also extends to their sizes. Not only do the cells in area $3 \mathrm{~b}$ and areas 1-2 have similar mean, maximum, and minimum diameters (Table I), but also the distribution patterns formed by grouping labeled cells of similar diameters together are very similar in the two areas sampled (Fig. 11). In each, two subpopulations of $\left[{ }^{3} \mathrm{H}\right] \mathrm{GABA}$-accumulating cells are present. One is made up of cells with somata 6 to $12 \mu \mathrm{m}$ in diameter, while the other is made up of cells 15 to $18 \mu \mathrm{m}$ in diameter or greater. The two peaks are particularly clear in the measurements obtained from the semi-thin section autoradiographs.

When the sizes of labeled cells in the individual layers of SI are examined, it is found that labeled cells in layer II and the adjacent part of layer III fall almost exclusively within the smaller diameter population. Although some cells have diameters greater than $12 \mu \mathrm{m}$, no cell in either layer is larger than $15 \mu \mathrm{m}$. By contrast, virtually all cells

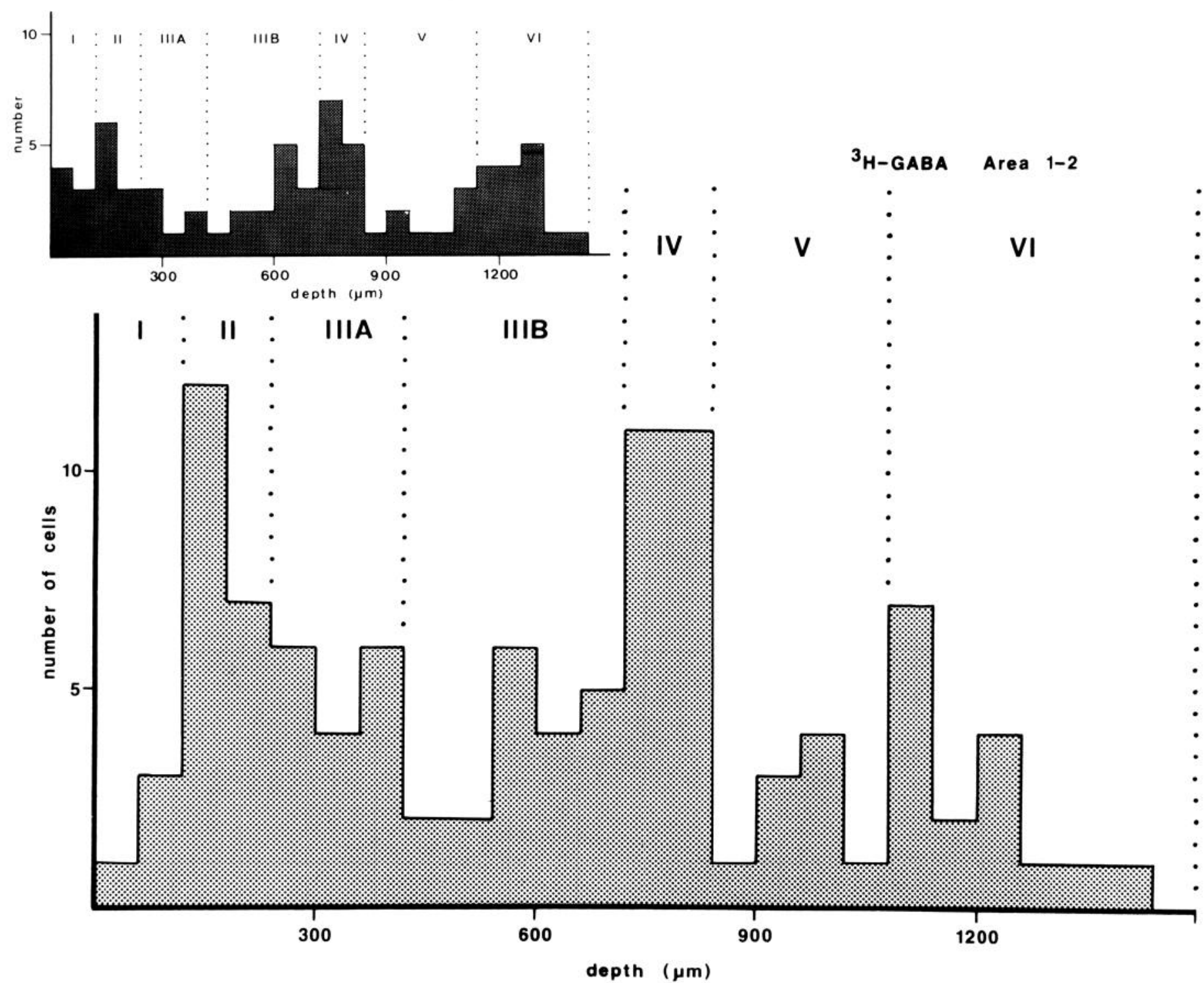

Figure 10. Distribution of labeled neuronal somata in a $430-\mu \mathrm{m}$-wide traverse across the cortex of areas 1-2. Note laminar concentrations are similar to those in area $3 \mathrm{~b}$. 

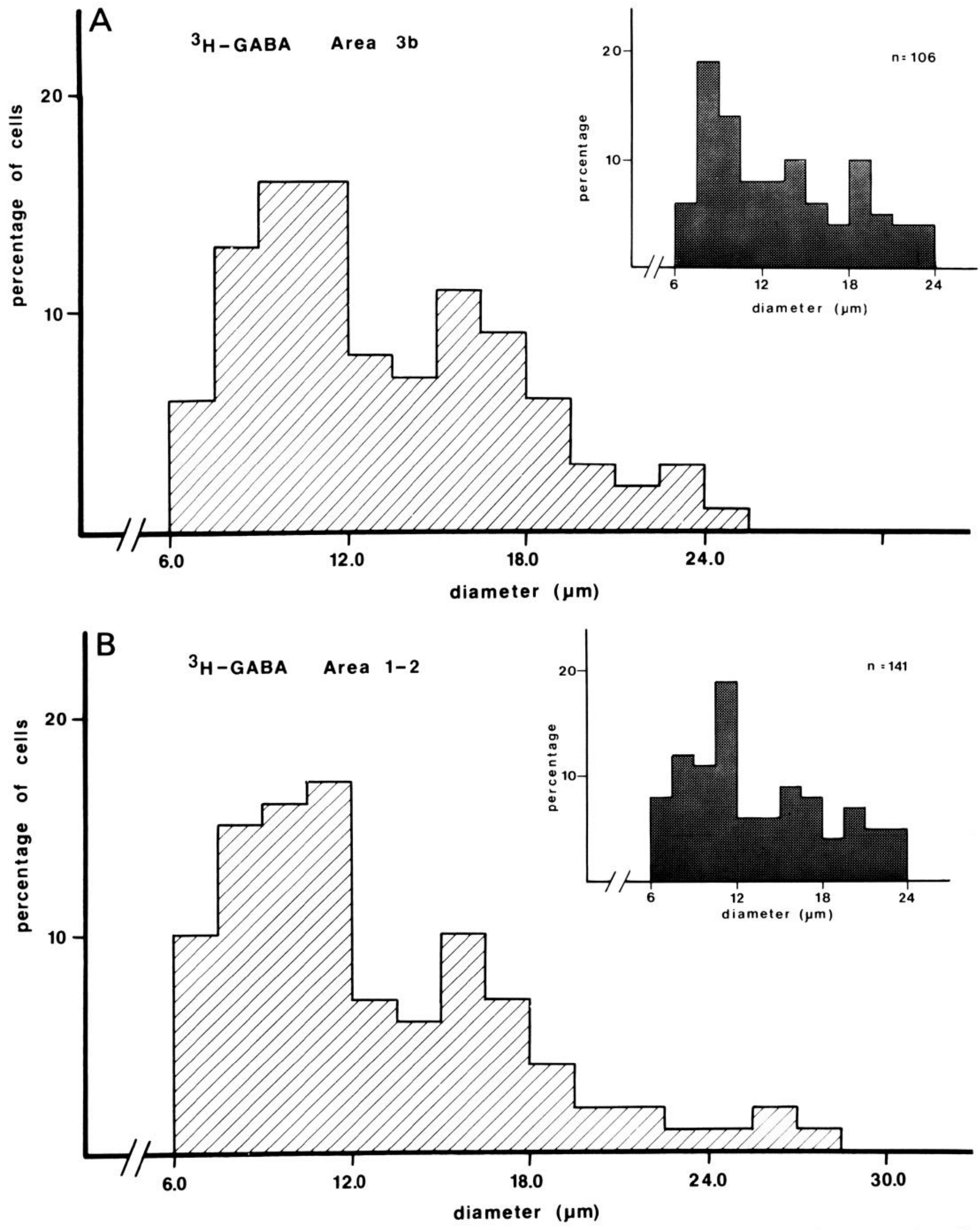

Figure 11. $A$ and $B$, Distribution patterns formed by grouping together labeled neuronal somata of similar diameter from all layers of the cortex of areas $3 \mathrm{~b}(A)$ and 1-2 $(B)$. Note in each case that there is a bimodal size spectrum with peaks at approximately 6 to $12 \mu \mathrm{m}$ and 15 to $20 \mu \mathrm{m}$. 


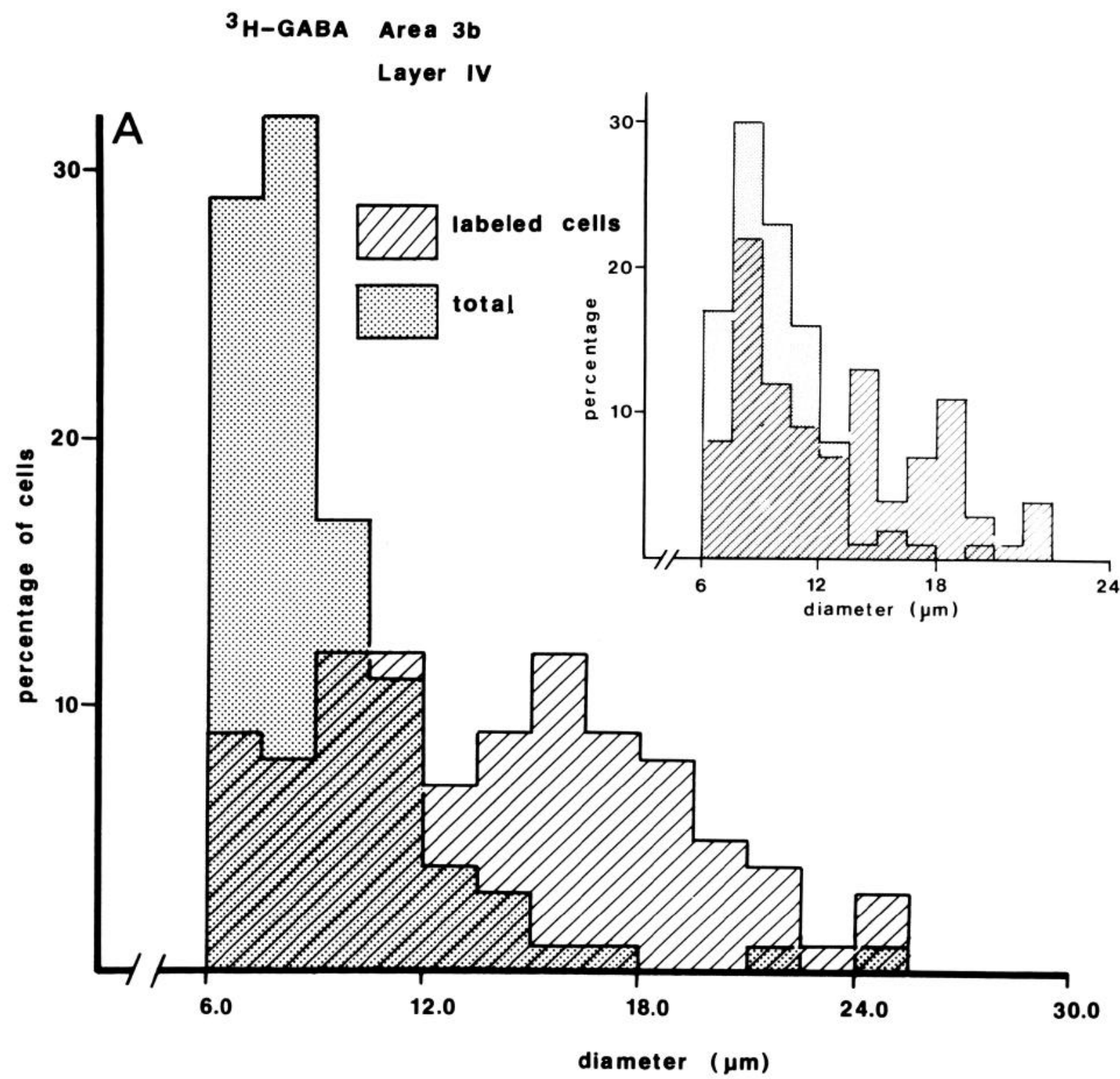

Figure 12. $A$ and $B$, Each main figure shows the percentage of labeled neuronal somata in areas $3 \mathrm{~b}(A)$ and $1-2(B)$ relative to the total population of neuronal somata in an unlabeled part of these areas. The data are from frozen sectioned material. Each inset shows the proportions of labeled and unlabeled neurons from the same $1-\mu \mathrm{m}$-thick plastic sections in which only neurons with identifiable nucleoli were measured.

in layer $\mathrm{V}$ are in the larger diameter population. In the deeper part of layer III, and in layers IV and VI, labeled cells are rather evenly divided between the smaller and larger diameter populations (Table I).

For layer IV, comparisons of sizes and numbers of labeled cells with those of all cells in the layer reveal that the labeled and total groups are not identical (Fig. 12). For all cells, the proportion in the smaller diameter range is much greater than that in the larger diameter range (90 to $92 \%$ versus 3 to $5 \%$ ). However, for labeled cells, the proportions in the two ranges are virtually identical; there are 41 to $46 \%$ in both the larger and smaller size ranges.

Area 5. The laminar distribution of labeled cells in area 5 differs from that in SI. In area 5 , as in SI, a large number of labeled cells are present in layer II and in layer VI (Fig. 13). However, the third peak, in layer IV, is not so obvious in area 5 (Fig. 13). This finding is a consistent one, both close to (zones II and III) and at a distance from (zone IV) the injection site.

In area 5 , the concentration of labeled cells in layer VI extends throughout the superficial half of the layer (Fig. 13) instead of being most marked at the layer V and VI border, as in SI (Figs. 9 and 10).

The sizes and distributions of labeled cells in area 5 are similar to those in SI (Table I; cf., Figs. 11 and 14) in all layers except layer IV (Fig. 14). In this layer, in area 5 , the proportion of smaller diameter labeled cells relative to the total population of cells in the layer is much smaller than in layer IV of areas 3b or 1-2 (Fig. 11).

Area 4. The laminar distribution of labeled cells in area 4 differs appreciably from that in either area 5 or 


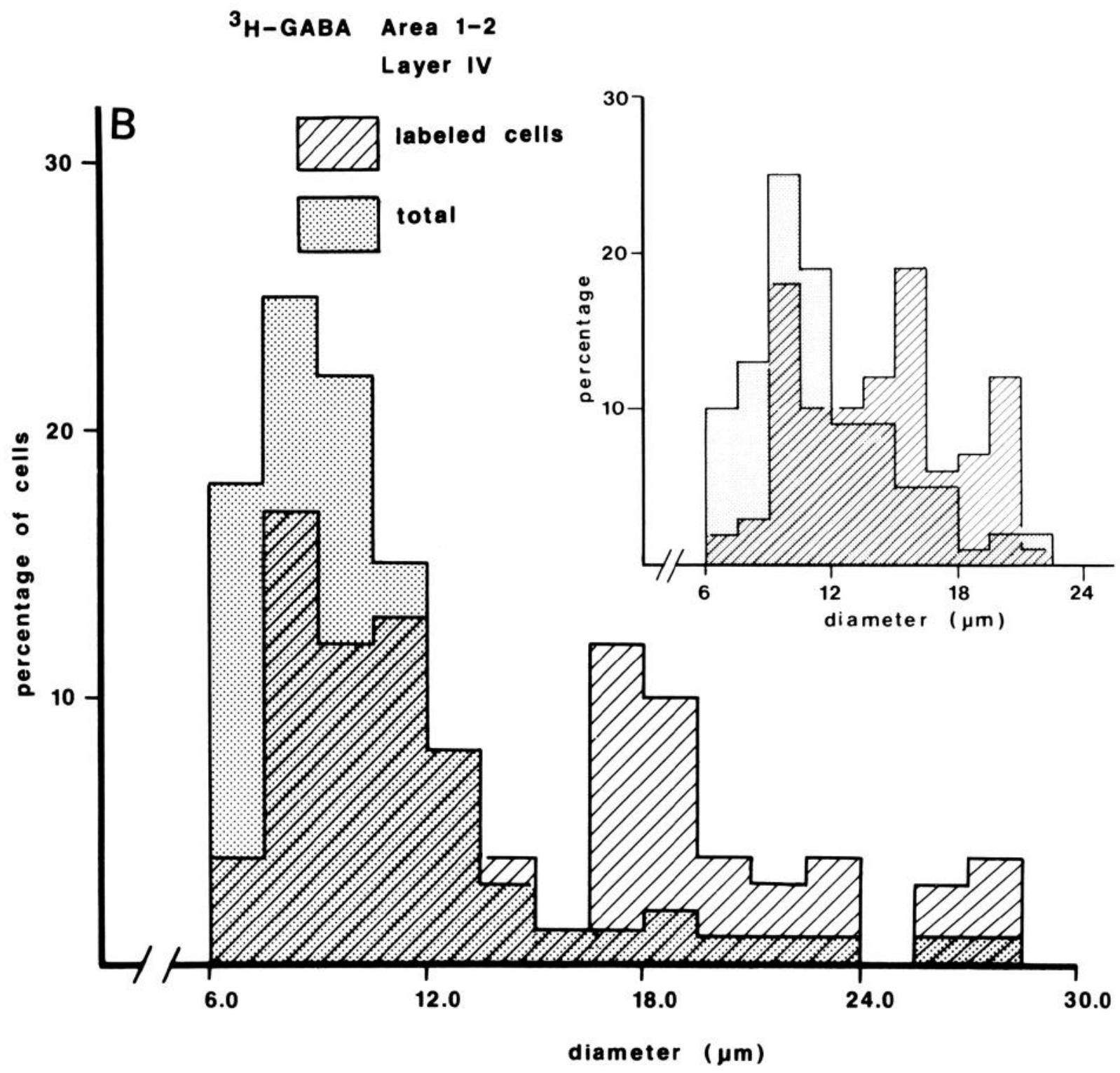

Figure 12. Continued.

SI. In area 4 , cell somata accumulating $\left[{ }^{3} \mathrm{H}\right] \mathrm{GABA}$ are distributed much more homogeneously (Fig. 15), with only relatively small and narrow peaks present in layer II, in the deeper part of layer III, and in layer V (Fig. 15). Moreover, the number of labeled cells in layer VI is rather smaller than in the other fields.

The diameters of labeled cells in area 4 are larger than those of cells in the other areas (Table I), but two ranges still are present (Fig. 16). The mean diameter of labeled cells in area 4 is more than $5 \mu \mathrm{m}$ greater than that found in the other areas, and the two peaks are at 9.0 to 13.5 $\mu \mathrm{m}$ and 21.0 to $27.0 \mu \mathrm{m}$. For comparison with the large labeled somata, the diameters of giant pyramidal cells in the arm representation of area 4 range from 25 to $50 \mu \mathrm{m}$. The overall increase in size of the labeled somata is presumably a reflection of the generally larger size of all neurons in area 4 in comparison with areas $3 \mathrm{~b}, 1-2$, and 5 . This same general increase in the diameter of labeled cells is also apparent when the layers of area 4 are examined individually (Table I).

\section{Discussion}

Though the accumulation of $\left[{ }^{3} \mathrm{H}\right] \mathrm{GABA}$ offers only an indirect guide to the identification of GABAergic neurons, we believe that our results probably give a reliable indication of the sizes and distribution of such cells in the fields that we have examined. In other sites, the method has been shown to label selectively neurons that are known to synthesize GABA and to utilize it as an inhibitory transmitter but not to label those that are known to use other transmitters (Iversen and Kelly, 1975; Brandon et al., 1979; Halasz et al., 1979). The injection of $\left[{ }^{3} \mathrm{H}\right]$ leucine led to a much more homogeneous pattern of labeling in the monkey cortex than that seen after $\left[{ }^{3} \mathrm{H}\right] \mathrm{GABA}$ injection, suggesting specificity in the labeling by the latter. In support of our belief that $\left[{ }^{3} \mathrm{H}\right] \mathrm{GABA}$ accumulates in GABAergic neurons in the monkey cortex are our findings made in collaboration with Drs. C. Houser and J. E. Vaughn. These show that the sizes and laminar distributions of neurons in areas $3 \mathrm{~b}, 1-2,4$, and 
TABLE I

Diameters of labeled cells

The mean diameter (standard deviation in parentheses), and the minimum and maximum diameters of $\left[{ }^{3} \mathrm{H}\right] \mathrm{GABA}$-labeled neuronal somata overall and in each of the layers of the four cytoarchitectonic areas studied, together with the percentages in the large and small size ranges are given. Data are from frozen section autoradiographs.

\begin{tabular}{|c|c|c|c|c|c|}
\hline & Mean & Minimum & $\begin{array}{l}\text { Maxi- } \\
\text { mum }\end{array}$ & \% $6-12 \mu \mathrm{m}$ & $\%>15 \mu \mathrm{m}$ \\
\hline Area $3 b$ Total & $13.6(4.5)$ & 6.1 & 25.2 & 51 & 34 \\
\hline Layer I & $8.7(1.1)$ & 6.8 & 12.5 & 98 & 0 \\
\hline II & $9.7(2.1)$ & 6.7 & 14.7 & 84 & 0 \\
\hline IIIA & $9.8(2.6)$ & 6.8 & 13.8 & 87 & 0 \\
\hline IIIB & $15.8(6.1)$ & 7.0 & 23.0 & 38 & 55 \\
\hline IV & $14.0(5.3)$ & 7.0 & 25.2 & 41 & 44 \\
\hline V & $15.7(4.9)$ & 7.1 & 26.2 & 33 & 59 \\
\hline VI & $13.5(4.0)$ & 6.1 & 24.5 & 36 & 51 \\
\hline Areas 1-2 Total & $12.3(5.1)$ & 6.1 & 27.2 & 58 & 30 \\
\hline Layer I & $8.3(1.4)$ & 6.2 & 11.8 & 100 & 0 \\
\hline II & $9.0(2.2)$ & 6.1 & 14.2 & 89 & 0 \\
\hline IIIA & $10.7(2.8)$ & 7.9 & 16.7 & 73 & 7 \\
\hline IIIB & $13.8(3.9)$ & 8.2 & 24.1 & 41 & 42 \\
\hline IV & $14.9(6.3)$ & 7.1 & 27.0 & 46 & 41 \\
\hline V & $14.9(5.3)$ & 6.4 & 27.2 & 41 & 49 \\
\hline VI & $13.6(4.3)$ & 7.1 & 26.1 & 44 & 47 \\
\hline Area 5 Total & $12.7(5.6)$ & 6.2 & 27.8 & 53 & 37 \\
\hline Layer I & $8.1(1.6)$ & 6.4 & 11.4 & 96 & 0 \\
\hline II & $8.7(2.1)$ & 6.2 & 13.4 & 87 & 0 \\
\hline IIIA & $10.1(3.1)$ & 7.7 & 16.2 & 78 & 4 \\
\hline IIIB & $14.4(4.2)$ & 7.6 & 25.4 & 39 & 46 \\
\hline IV & $14.5(6.7)$ & 7.3 & 26.7 & 27 & 61 \\
\hline V & $15.6(5.9)$ & 7.0 & 27.8 & 37 & 56 \\
\hline VI & $14.0(3.9)$ & 6.8 & 25.4 & 40 & 48 \\
\hline Area 4 Total & $18.4(7.2)$ & 7.3 & 33.5 & 25 & 60 \\
\hline Layer I & $10.1(0.8)$ & 8.0 & 10.6 & 89 & 0 \\
\hline II & $11.2(2.4)$ & 7.3 & 16.8 & 63 & 13 \\
\hline IIIA & $15.7(5.9)$ & 9.2 & 25.1 & 33 & 48 \\
\hline IIIB & $21.7(7.1)$ & 8.8 & 33.5 & 9 & 86 \\
\hline V & $20.1(6.6)$ & 9.9 & 32.4 & 9 & 74 \\
\hline VI & $20.4(4.9)$ & 9.9 & 29.2 & 8 & 82 \\
\hline
\end{tabular}

5 labeled immunocytochemically for glutamic acid decarboxylase (GAD) are identical to those labeled by $\left[{ }^{3} \mathrm{H}\right]-$ GABA uptake (Houser et al., 1980). Moreover, the proportions of GAD-positive somata are roughly comparable to those labeled in zone III by $\left[{ }^{3} \mathrm{H}\right] \mathrm{GABA}$ uptake. Nevertheless, some degree of caution still must be expressed first, because GABA-mediated inhibition in the cortex has not been correlated yet with particular cell classes and, second, because we do not know whether some class of GABAergic cortical cell may be refractory to labeling with $\left[{ }^{3} \mathrm{H}\right] \mathrm{GABA}$, as is the Purkinje cell of the cerebellum (Hökfelt and Ljungdahl, 1972; Schon and Iversen, 1972; Iversen and Kelly, 1975; Kelly and Dick, 1976).

Our results are probably best interpreted as indicating that all neurons accumulating $\left[{ }^{3} \mathrm{H}\right] \mathrm{GABA}$ have axons that remain intrinsic to the cortex. No obvious pyramidal cells could be labeled except at the very center of the injection site where all cells were labeled. The pyramidal cells form the only efferent cells of the monkey sensorymotor cortex (Jones and Wise, 1977). Their terminals, where demonstrated electron microscopically, have not been shown to have the morphological features, such as flattened vesicles and symmetric membrane complexes, associated with GABAergic transmission elsewhere (e.g., Holländer et al., 1969; Jones and Powell, 1969b; Kemp and Powell, 1971; Lund, 1972; Brown, 1974; Rustioni and Sotelo, 1974). And, there are no indications of GABA as a transmitter in any corticofugal system. We think that the small amount of axonal labeling seen entering the white matter beneath the center of the injection site is probably anterograde in character and that it probably represents transport of $\left[{ }^{3} \mathrm{H}\right] \mathrm{GABA}$ that has been accumulated nonspecifically by pyramidal cells at the heart of the injection site or of labeled residues of GABA metabolism that have been incorporated into axoplasmically transported macromolecules.

Though we feel that the evidence is good that only intrinsic cortical neurons specifically accumulate $\left[{ }^{3} \mathrm{H}\right]$ GABA, it seems clear that not all intrinsic neurons do so. This is particularly obvious in layer IV of areas $3 b, 1-2$, and 5 which contains no efferent cell somata (Jones and Wise, 1977) and in which only about $40 \%$ of the somata present are labeled. This would correlate with the view that the small spiny neuron of this layer, which is a major recipient of thalamic axon terminals, is excitatory in character (Jones, 1980) and, therefore, is unlabeled.

Two classes of intrinsic neuron that accumulate $\left[{ }^{3} \mathrm{H}\right]$ GABA can be recognized on the basis of somal size. We consider that the measurements made on semi-thin autoradiographs, in which we usually could identify positively neurons from glial cells and see the nucleolus in the neurons measured, compensate for problems arising from difficulty of identification or from measuring profiles of large neuronal somata sectioned near their edges. In the data from the semi-thin sections, the movement of the small-celled peak to the right suggests some inclusion of glial cells and the deepening of the trough between the two peaks suggests some inclusion of partial profiles in the data from the frozen sections. However, the differences are not marked.

Rather disappointingly, labeled processes could be distinguished only on the larger form of labeled neuron. It is difficult to avoid the conclusion that the largest of the large labeled form, approaching in size that of the largest pyramidal cell, is the large, multipolar, basket cell of the neocortex (Marin-Padilla, 1971; Jones, 1975; Fig. 17). In the monkey sensory-motor cortex and in the human motor cortex, these are the only intrinsic neurons with large somata and the somata are concentrated in layers III and $\mathrm{V}$ though they have dendrites extending through most other layers. The branches of the axons, which may be myelinated (Jones, 1975), are oriented anteroposteriorly across the pre- and postcentral gyri and terminate in basket-like formations embracing the somata of pyramidal cells. Synaptic terminals in this position contain flattened vesicles and make symmetric synapses (Colonnier, 1968; Jones and Powell, 1970a; Peters and Kaiserman-Abramof, 1970; Gatter et al., 1978). Finally, the large multipolar cells and the terminals on pyramidal cells label intensely with antiserum to glutamic acid decarboxylase (Houser et al., 1980), confirming the work on the 


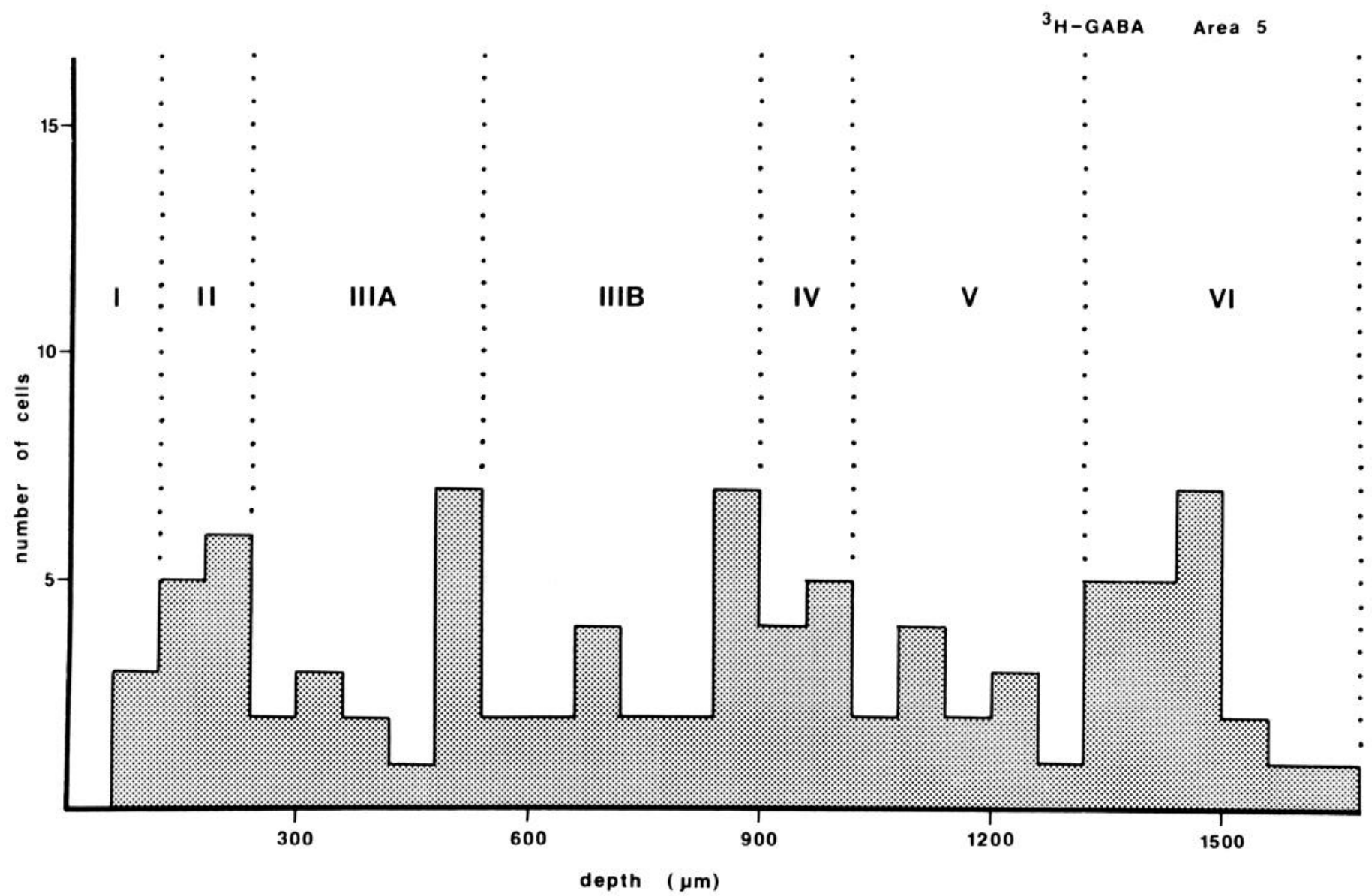

Figure 13. Distribution of labeled neuronal somata in a 430- $\mu \mathrm{m}$-wide traverse across the cortex of area 5 . Laminar concentrations similar to those in areas $3 \mathrm{~b}$ and 1-2 are observed though the peak in layer $I V$ is not so obvious. The data are from frozen section autoradiographs only.

rat visual cortex by Ribak (1978). Unfortunately, we could not detect the terminals to be labeled by $\left[{ }^{3} \mathrm{H}\right]-$ GABA uptake. The stereotyped orientation and distribution of the axon of the basket cell, coupled with the evidence for its use of GABA as a transmitter, makes it a suitable candidate for mediating the effect originally described in the sensory cortex by Mountcastle and Powell (1959), in which activation of one place- and modalityspecific column of cells is accompanied by inhibition of adjacent columns (Jones, 1980).

The smaller size range of $\left[{ }^{3} \mathrm{H}\right] \mathrm{GABA}$-accumulating cells may well contain several of the classes of intrinsic neuron recognized in Golgi preparations. It is impossible to predict which classes may be involved at this stage but certain of them would seem appropriate (Fig. 17). In layer IV, the "spider web cell" of Cajal (Ramón y Cajal, 1911) or type 5 cell of Jones (1975), with its intensely intertwined unmyelinated axon, embracing the somata of several hundred small spiny neurons (Valverde, 1971), has strong resemblances to the Golgi cell of the cerebellar cortex which is known to synthesize GABA. The spider web cell has been predicted to be favorably placed to mediate an inhibitory "focusing" effect upon focal thalamic input zones in the somatic sensory cortex (Jones,
1980). In layer III, the "chandelier cell" of Szentágothai (1973) or type 4 cell of Jones (1975) has been shown in the cat and rat visual cortex to possess terminals that contain flattened vesicles and end in symmetric contacts on the initial axon segments of pyramidal cells (Somogyi, 1977). In this position, in the rat, similar synapses are GAD positive (Ribak, 1978). The type 4 cell, therefore, would also be a suitable candidate for a GABAergic cell. Whether it, the spider web cell, or the basket cell receive monosynaptic thalamocortical inputs is not established yet, but monosynaptic inputs have been described to cortical inhibitory neurons (Stefanis, 1969; Stone, 1973; Toyama et al., 1974), and degenerating thalamocortical terminals have been observed on non-spiny dendrites of the type possessed by each cell (Jones and Powell, 1970b; Strick and Sterling, 1974; Peters and Feldman, 1976; Sloper and Powell, 1979b).

In layers I and II, the small basket cell of Szentágothai (1973) or the type 6 cell of Jones (1975) may be a possibility to account for the concentration of $\left[{ }^{3} \mathrm{H}\right]$ GABA-accumulating cells in those layers. Possibly, the association of many of the labeled cells in layer I with the zone of non-somal labeling in the superficial part of the layer indicates axonal labeling by anterograde or 

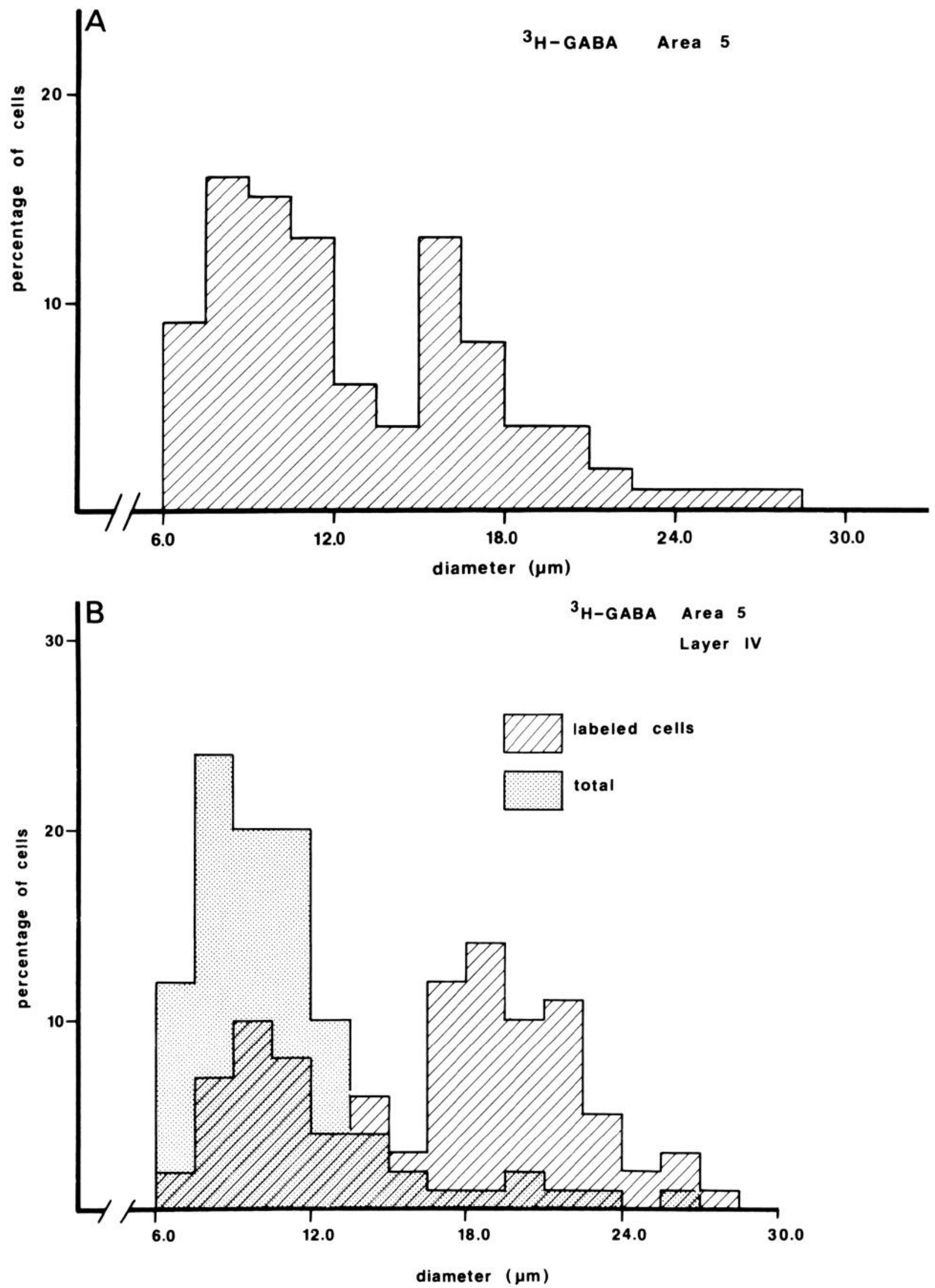

Figure 14. $A$ and $B$, Bimodal size spectrum of labeled somata in area $5(A)$ corresponds to that in areas $3 \mathrm{~b}$ and $1-2$. The percentage of small labeled somata $(B)$ in area 5 is rather smaller than that in areas $3 \mathrm{~b}$ and $1-2$. The data are from frozen section autoradiographs only. 

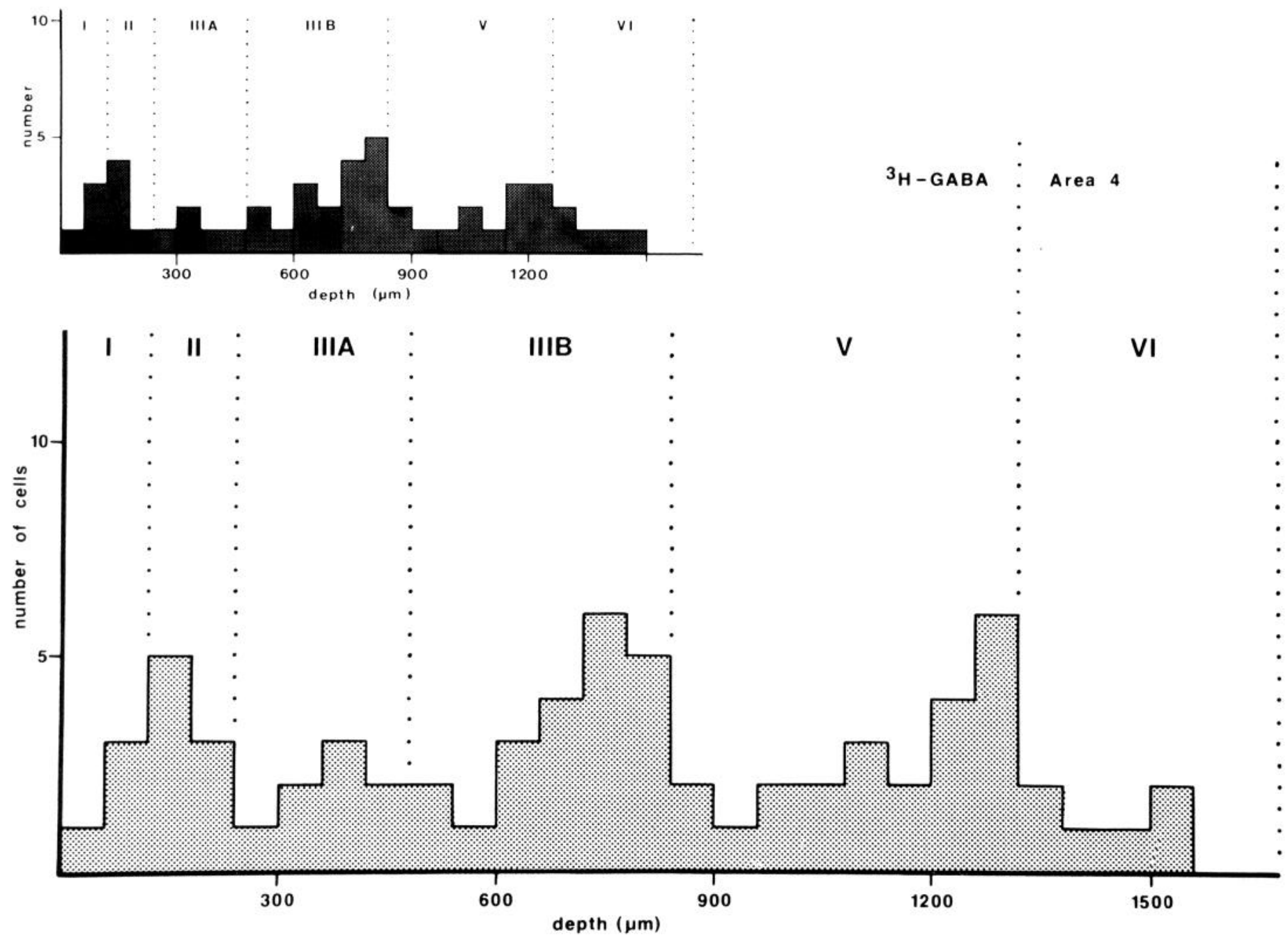

Figure 15. Laminar distribution of labeled neuronal somata in a 430 - $\mu \mathrm{m}$-wide traverse across area 4 . Note relatively smaller number of labeled cells in layer VI in comparison with areas $3 \mathrm{~b}, 1-2$, and 5 . The data are from frozen and plastic section autoradiographs.

retrograde transport of $\left[{ }^{3} \mathrm{H}\right] \mathrm{GABA}$ in their axons. However, it is difficult to rule out that this superficial labeling merely results from diffusion of the injected material through the subarachnoid space. We think it unlikely, however, that the more deeply situated labeled cells of layer I accumulate $\left[{ }^{3} \mathrm{H}\right] \mathrm{GABA}$ by this route.

It is difficult to correlate any of the other intrinsic cortical neurons with the present results, principally because of lack of information about their synaptic organization. It seems unlikely that those with vertical axons (Fig. 17) that terminate on dendritic spines of pyramidal cells would be GABAergic since most terminations on spines have the characteristics usually associated with excitatory synapses (Jones and Powell, 1969b; Peters and Kaiserman-Abramof, 1970; LeVay, 1973; Sloper and Powell, 1979a). Similarly, the large multipolar, peptidergic cell (Emson and Hunt, 1980) also may not be a suitable candidate for a GABAergic neuron. However, certain other types remain and there is very little information about intrinsic neurons in layer VI, the superficial part of which contains one of the main concentrations of $\left[{ }^{3} \mathrm{H}\right] \mathrm{GABA}$-accumulating neurons.
Little significance can be attached at present to the differences in the laminar distribution of $\left[{ }^{3} \mathrm{H}\right] \mathrm{GABA}$ accumulating neurons in areas $3 b, 1-2,4$, and 5 . The principal differences in area 4 probably result mainly from the greater cell size, greatly increased thickness of the cortex and absence of a layer IV. The reduction of small $\left[{ }^{3} \mathrm{H}\right]$ GABA-accumulating neurons in layer IV of area 5 in comparison with the other areas is difficult to interpret, but it is interesting to note that, in this area, thalamic afferent fibers terminate not in layer IV but in the overlying layer III (Jones and Burton, 1976). Conceivably, one class of GABAergic neuron follows closely the distribution of the thalamic afferents, though this explanation cannot hold in areas 1 and 2 in which the thalamic terminations also are distributed only to layer III. Perhaps the zone of GABAergic somata in the superficial part of layer VI also may correlate in some as yet undefined way with the presence there of a subsidiary zone of thalamic terminations (Jones and Burton, 1976; Sloper and Powell, 1979b).

Labeling of neuroglial cells by uptake of $\left[{ }^{3} \mathrm{H}\right] \mathrm{GABA}$ has not constituted a major source of misinterpretation 


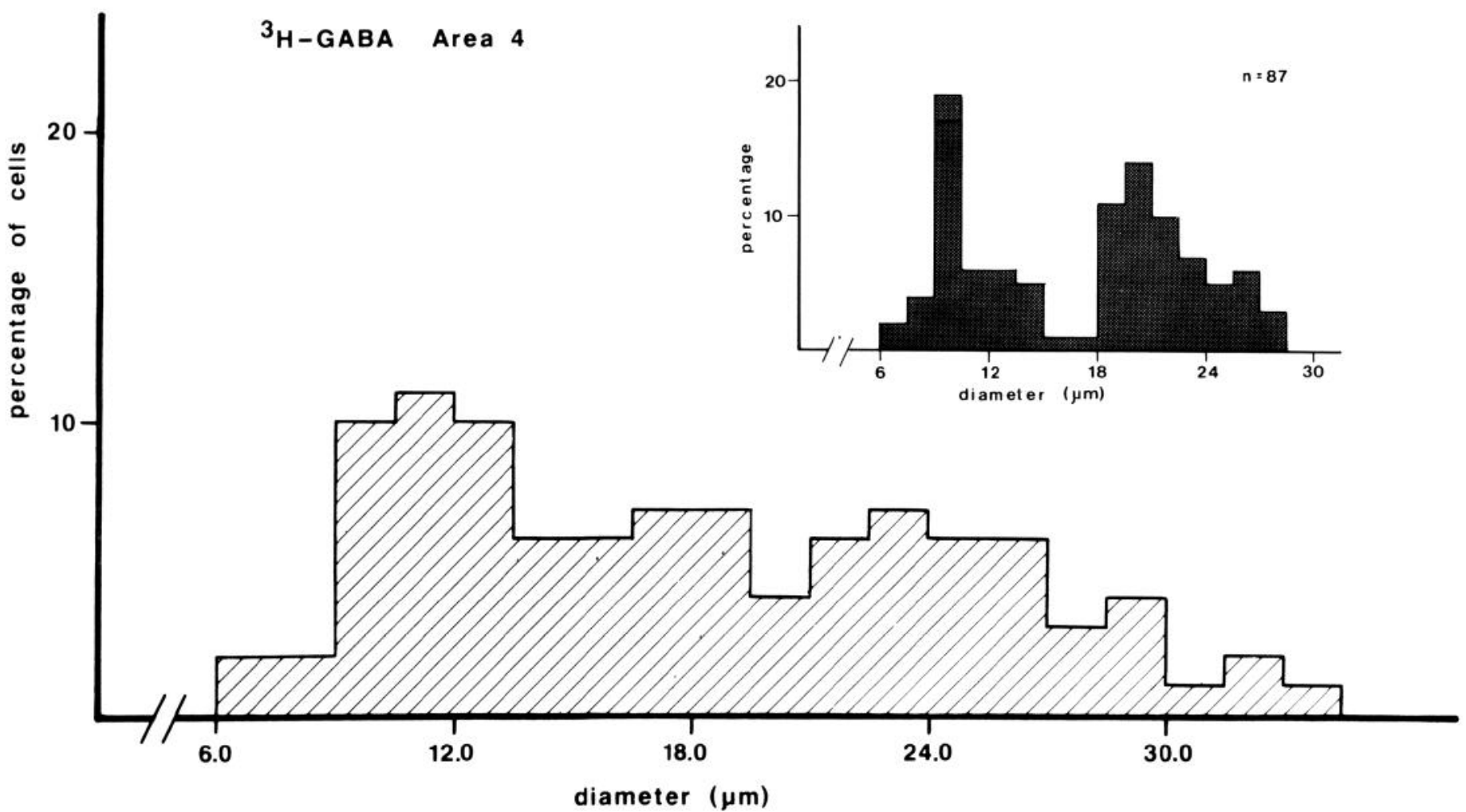

Figure 16. Size spectrum of labeled somata in area 4 shows that, in comparison with areas $3 \mathrm{~b}, 1-2$, and 5 , the labeled cells are generally larger, but the bimodal distribution persists. The data in the main figure are from frozen section autoradiographs; the data in the inset are from a 1- $\mu$ m-thick plastic section.

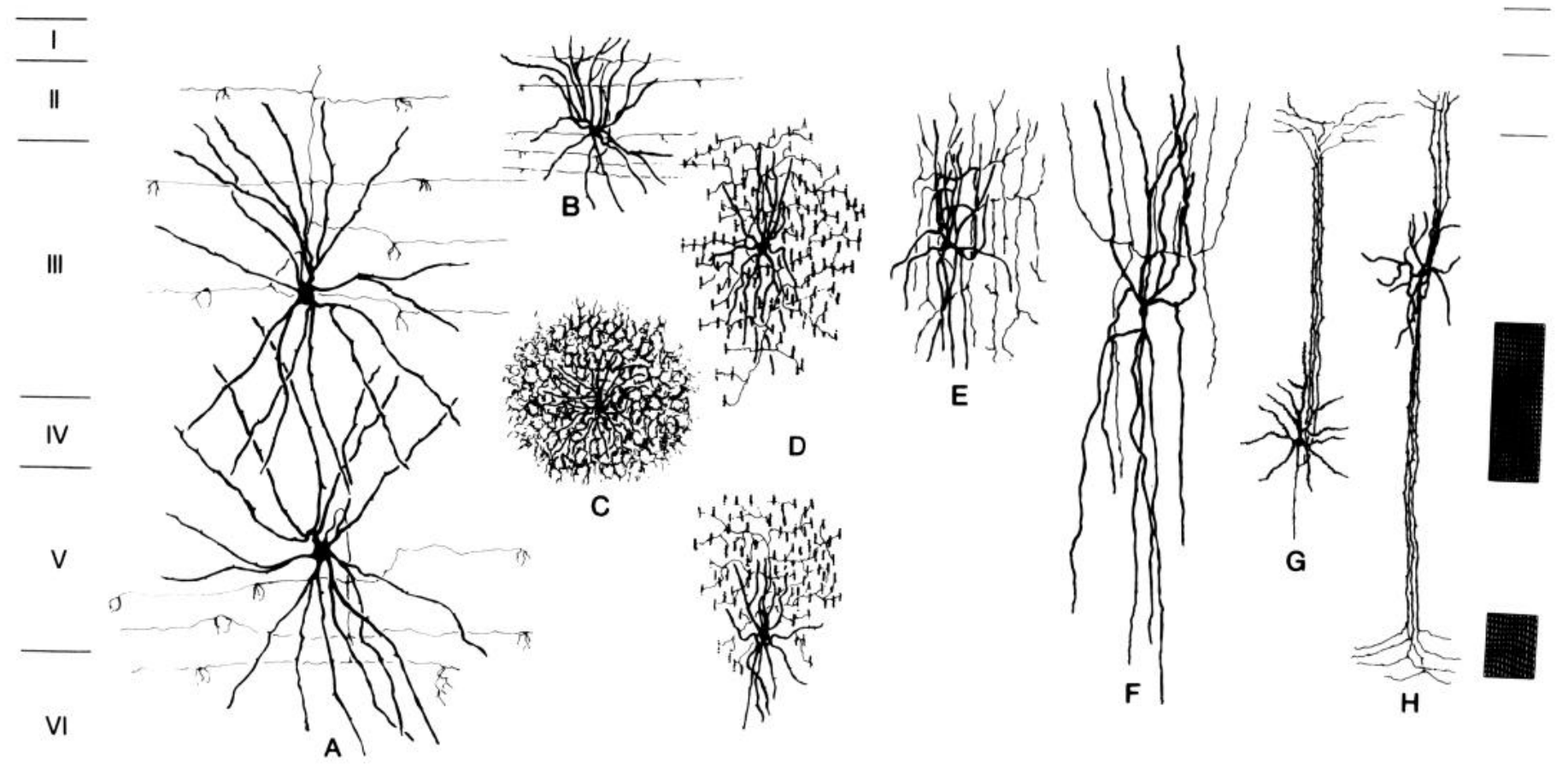

Figure 17. Schematic figure after camera lucida drawings of Golgi preparations of Jones (1975) and modified from Jon $\bullet$ s (1980), showing the several classes of intrinsic neuron found in the monkey somatic sensory cortex, all drawn at the same magnification. For reasons discussed in text, large multipolar, basket cells $(A)$ probably correspond to the largest GABA-labeled cells of the present study. Other likely candidates for small GABA-concentrating cells are the small basket cells $(B)$ of layer $I I$, the spider web cell $(C)$ of layer $I V$, and the chandelier cell $(D)$ of layers $I I I$ and $V$. Layer III cell $(E)$ with axonal arcades cannot be predicted; very elongated cell $(F)$ may be peptidergic; double bouquet cell $(H)$ of layers $I I$ and $I I I$ and spiny cell $(G)$ of $l a y e r ~ I V$ are likely to be excitatory in character. Bars to the right indicate laminar zones of termination of thalamic afferents in area $3 \mathrm{~b}$. 
in our results. In the heart of the injection site, we have confirmed that glial cells do accumulate the labeled material (Hökfelt and Ljungdahl, 1971; Orkand and Kravitz, 1971; Iversen and Kelly, 1975; Kelly and Dick, 1976; Hösli and Hösli, 1978; Halasz et al., 1979). However, in the zone in which we made our quantitative assessments, glial cell labeling seemed to be greatly reduced or absent. In the semi-thin autoradiographs, even the smallest labeled somata could be seen to be larger than those of the unlabeled glial cells. Though glial cells may play an important role in the metabolism of GABA (Iversen and Kelly, 1975), this role does not appear to have been manifest nor a source of confusion in the zone in which we made counts and measurements.

\section{References}

Brandon, C., D. M. K. Lam, and J. Y Wu (1979) The $\gamma$ aminobutyric acid system in rabbit retina: Localization by immunocytochemistry and autoradiography. Proc. Natl. Acad. Sci. U. S. A. 76: 3557-3561.

Brown, L. T. (1974) Corticorubral projections in the cat. J. Comp. Neurol. 154: 149-168.

Chronwall, B. M., and J. R. Wolff (1978) Classification and location of neurons taking up $\left[{ }^{3} \mathrm{H}\right]$-GABA in the visual cortex of rats. In Amino Acids as Chemical Transmitters, F. Fonnum, ed., pp. 297-303, Plenum, New York.

Chronwall, B., and J. B. Wolff (1980) Prenatal and postnatal development of GABA-accumulating cells in the occipital neocortex of the rat. J. Comp. Neurol. 190: 187-208.

Colonnier, M. (1968) Synaptic patterns on different cell types in the different laminae of the cat visual cortex. An electron microscope study. Brain Res. 9: 268-287.

Cowan, W. M., and D. Wann (1973) A computer system for the measurement of cell and nuclear sizes. J. Microsc. 99: 331348.

Crawford, J. M., and D. R. Curtis (1964) The excitation and depression of mammalian cortical neurones by amino acids. Br. J. Pharmacol. Chemother. 23: 313-329.

Dichter, M. A. (1980) Physiological identification of GABA as the inhibitory transmitter for mammalian cortical neurons in cell culture. Brain Res. 190: 111-121.

Dreifuss, J. J., J. S. Kelly, and K. Krnjevíc (1969) Cortical inhibition and $\gamma$-aminobutyric acid. Exp. Brain Res. 9: 137154.

Duffy, F. H., S. R. Snodgrass, J. L. Burchfiel, and J. L. Conway (1976) Bicuculline reversal of deprivation amblyopia in the cat. Nature 260: 256-257.

Emson, P. C., and S. P. Hunt (1980) Anatomical chemistry of the cerebral cortex. In The Cerebral Cortex, F. O. Schmitt, F. G. Worden, and S. G. Dennis, eds., MIT Press, Cambridge, MA, in press.

Emson, P. C., and O. Lindvall (1979) Distribution of putative neurotransmitters in the neocortex. Neuroscience 4: 14071439.

Feldman, M. L., and A. Peters (1978) The forms of non-pyramidal neurons in the visual cortex of the rat. J. Comp. Neurol. 179: 761-794.

Gatter, K. C., J. J. Sloper, and T. P. S. Powell (1978) An electron microscopic study of the termination of intracortical axons upon Betz cells in area 4 of the monkey. Brain 101: $543-553$

Halasz, N., A. Ljungdahl, and T. Hökfelt (1979) Transmitter histochemistry of the rat olfactory bulb. III. Autoradiographic localization of [ $\left.{ }^{3} \mathrm{H}\right]$-GABA. Brain Res. 167: 221-240.

Hendry, S. H. C., and E. G. Jones (1980) Selective uptake of $\left[{ }^{3} \mathrm{H}\right]$-GABA by interneurons in monkey sensory-motor cortex. Soc. Neurosci. Abstr. 6: 654 .
Hökfelt, T., and A. Ljungdahl (1971) Uptake of $\left[{ }^{3} \mathrm{H}\right]$ noradrenaline and $\left[{ }^{3} \mathrm{H}\right]$ gamma-aminobutyric acid in isolated tissues of rat: An autoradiographic and fluorescence microscopic study. In Histochemistry of Nervous Transmission, Progress in Brain Research, O. Eränkö, ed., Vol. 34, pp. 87-102, Elsevier, Amsterdam.

Hökfelt, T., and $\AA$. Ljungdahl (1972) Autoradiographic identification of cerebral and cerebellar cortical neurons accumulating labeled gamma-aminobutyric acid $\left({ }^{3} \mathrm{H}-\mathrm{GABA}\right)$. Exp. Brain Res. 14: 354-362.

Holländer, H., P. Brodal, and F. Walberg (1969) Electron microscopic observations on the structure of the pontine nuclei and the mode of termination of the corticopontine fibers. An experimental study in the cat. Exp. Brain Res. 7: 95-110.

Hösli, L., and E. Hösli (1978) Action and uptake of neurotransmitters in CNS tissue cultures. Rev. Physiol. Biochem. Pharmacol. 81: 135-188.

Houser, C., J. E. Vaughn, E. G. Jones, and S. H. C. Hendry (1980) GABA neurons of monkey motor and sensory cortex: An immunocytochemical study. Soc. Neurosci. Abstr. 6: 159.

Hubel, D. H., and T. N. Wiesel (1965) Receptive fields and functional architecture in two non-striate visual areas (18 and 19 ) of the cat. J. Neurophysiol. 28: 229-289.

Iversen, L. L., and J. S. Kelly (1975) Uptake and metabolism of $\gamma$-aminobutyric acid by neurones and glial cells. Biochem. Pharmacol. 34: 933-938.

Iversen, L. L., J. F. Mitchell, and V. Srinivarsan (1971) The release of $\gamma$-aminobutyric acid during inhibition in the cat visual cortex. J. Physiol. (Lond.) 212: 519-534.

Jones, E. G. (1975) Varieties and distribution of non-pyramidal cells in the somatic sensory cortex of the squirrel monkey. $J$. Comp. Neurol. 160: 205-268.

Jones, E. G. (1980) Anatomy of cerebral cortex: Columnar input-output organization. In The Cerebral Cortex, F. O. Schmitt, E. G. Worden, and M. Dennis, eds., MIT Press, Cambridge, MA, in press.

Jones, E. G., and H. Burton (1976) Areal differences in the laminar distribution of thalamic afferents in cortical fields of the insular, parietal, and temporal regions of primates. $\mathrm{J}$. Comp. Neurol. 168: 197-248.

Jones, E. G., and T. P. S. Powell (1969a) Morphological variations in the dendritic spines of the neocortex. J. Cell Sci. 5: 509-529.

Jones, E. G., and T. P. S. Powell (1969b) An electron microscopic study of the mode of termination of corticothalamic fibres in the thalamic relay nuclei of the cat. Proc. R. Soc. Lond. (Biol.) 172: 173-185.

Jones, E. G., and T. P. S. Powell (1970a) An electron microscopic study of the laminar pattern and mode of termination of afferent fibre pathways in the somatic sensory cortex of the cat. Philos. Trans. R. Soc. Lond. (Biol.) 257: 45-62.

Jones, E. G., and T. P. S. Powell (1970b) Electron microscopy of the somatic sensory cortex of the cat. I. Cell types and synaptic organization. Philos. Trans. R. Soc. Lond. (Biol.) 257: 1-11.

Jones, E. G., and S. P. Wise (1977) Size, laminar and columnar distribution of efferent cells in the sensory-motor cortex of monkeys. J. Comp. Neurol. 175: 391-438.

Kelly, J. S., and F. Dick (1976) Differential labeling of glial cells and GABA-inhibitory interneurons and nerve terminals following microinjection of $\left[\beta{ }^{3} \mathrm{H}\right]$ alanine, $\left[{ }^{3} \mathrm{H}\right] \mathrm{DABA}$ and $\left[{ }^{3} \mathrm{H}\right]$-GABA into single folia of the cerebellum. Cold Spring Harbor Symp. Quant. Biol. 40: 93-106.

Kemp, J. M., and T. P. S. Powell (1971) The site of termination of afferent fibres in the caudate nucleus. Philos. Trans. $R$. Soc. Lond. (Biol.) 262: 413-427.

Krnjevic, K. (1974) Chemical nature of synaptic transmission in vertebrates. Physiol. Rev. 54: 318-450. 
Krnjevíc, K., and J. W. Phillis (1963) Iontophoretic studies of neurones in the mammalian cerebral cortex. J. Physiol. (Lond.) 165: 274-304.

Krnjevíc, K., and S. Schwartz (1967) The action of $\gamma$-aminobutyric acid on cortical neurones. Exp. Brain Res. 3: 320-326.

LeVay, S. (1973) Synaptic patterns in the visual cortex of the cat and monkey. Electron microscopy of Golgi preparations. J. Comp. Neurol. 150: 53-86.

Lund, R. D. (1972) Synaptic patterns in the superficial layers of the superior colliculus of the monkey, Macaca mulatta. Exp. Brain Res. 15: 194-216.

Marin-Padilla, M. (1971) Prenatal and early postnatal ontogenesis of the human motor cortex: A Golgi study. II. The basketpyramidal system. Brain Res. 23: 185-192.

Mountcastle, V. B., and T. P. S. Powell (1959) Neural mechanisms subserving cutaneous sensibility, with special reference to the role of afferent inhibition in sensory perception and discrimination. Bull. Johns Hopkins Hosp. 105: 201-232.

Neal, M. J., and L. L. Iversen (1969) Subcellular distribution of endogenous and $\left[{ }^{3} \mathrm{H}\right] \gamma$-aminobutyric acid in rat cerebral cortex. J. Neurochem. 16: 1245-1252.

Orkand, P. M., and E. A. Kravitz (1971) Localization of the sites of $\gamma$-aminobutyric acid (GABA) uptake in lobster nerve muscle preparation. J. Cell Biol. 49: 75-89.

Peters, A., and M. L. Feldman (1976) The projection of the lateral geniculate nucleus to area 17 of the rat cerebral cortex. I. General description. J. Neurocytol. 3: 63-84.

Peters, A., and I. Kaiserman-Abramof (1970) The small pyramidal neuron of the rat cerebral cortex. The perikaryon, dendrites, and spines. Am. J. Anat. 127: 321-355.

Ramón y Cajal, S. (1911) Histologie du systéme nerveux de l'homme et des vertébrés, S. Azoulay, translator, Vol. 2, Maloine, Paris.

Ribak, C. E. (1978) Aspinous and sparsely-spinous stellate neurons in the visual cortex of rats contain glutamic acid decarboxylase. J. Neurocytol. 7: 461-478.

Rustioni, A., and C. Sotelo (1974) Synaptic organization of the nucleus gracilis of the cat. Experimental identification of dorsal root fibers and cortical afferents. J. Comp. Neurol. 155: 441-467.

Schon, F., and L. L. Iversen (1972) Selective accumulation of [ $\left.{ }^{3} \mathrm{H}\right]-\mathrm{GABA}$ by stellate cells in rat cerebellar cortex in vivo. Brain Res 42: 503-507.

Sillito, A. M. (1975) The contribution of inhibitory mechanisms to the receptive field properties of neurones in the striate cortex of the cat. J. Physiol. (Lond.) 250: 305-329.

Sillito, A. M. (1977a) Inhibitory processes underlying the directional specificity of simple, complex and hypercomplex cells in the cat's visual cortex. J. Physiol. (Lond.) 271: 699-720.
Sillito, A. M. (1977b) The spatial extent of excitatory and inhibitory zones in the receptive field of superficial layer hypercomplex cells. J. Physiol. (Lond.) 273: 791-803.

Sillito, A. M. (1979) Inhibitory mechanisms influencing complex cell orientation selectivity and their modification at high resting discharge levels. J. Physiol. (Lond.) 289: 33-53.

Sillito, A. M., and V. Versiani (1977) The contribution of excitatory and inhibitory inputs to the length preference of hypercomplex cells in layers II and III of the cat's striate cortex. J. Physiol. (Lond.) 273: 775-790.

Sloper, J. J., and 'T. P.S. Powell (1979a) Ultrastructural features of the sensori-motor cortex of the primate. Philos. Trans. R. Soc. Lond. (Biol.) 285: 123-139.

Sloper, J. J., and T. P. S. Powell (1979b) An experimental electron microscopic study of afferent connections to the primate motor and somatic sensory cortices. Philos. Trans. R. Soc. Lond. (Biol.) 285: 199-226.

Somogyi, P. (1977) A specific axo-axonal interneuron in the visual cortex of the rat. Brain Res. 136: 345-350.

Stefanis, C. (1969) Interneuronal mechanisms in the cortex. In The Interneuron, M. A. B. Brazier, ed., pp. 497-526, University of California Press, Los Angeles.

Stone, T. W. (1973) Cortical pyramidal tract interneurones and their sensitivity to L-glutamic acid. J. Physiol. (Lond.) 233: 211-225.

Strick, P. L., and P. Sterling (1974) Synaptic termination of afferents from the ventrolateral nucleus of the thalamus in the cat motor cortex. A light and electron microscope study. Brain Res. 61: 218-241.

Szentágothai, J. (1973) Synaptology of the visual cortex. In Handbook of Sensory Physiology. Vol. VII/3: Central Processing of Visual Information. Part B: Visual Centers of the Brain, R. Jung, ed., pp. 269-324, Springer, Berlin.

Toyama, K., K. Matsunami, T. Ohno, and S. Tohashiki (1974) An intracellular study of neuronal organization in the visual cortex. Exp. Brain Res. 21: 45-66.

Tsumoto, T., W. Eckart, and O. D. Creutzfeldt (1979) Modification of orientation sensitivity of cat visual cortex neurons by removal of GABA-mediated inhibition. Exp. Brain Res. 34: 351-365.

Valverde, F. (1971) Short axon neuronal subsystems in the visual cortex of the monkey. Int. J. Neurosci. 1: 181-197.

Wallach, D. P. (1961) Studies on the GABA pathway. The inhibition of $\gamma$-aminobutyric acid- $\alpha$-ketoglutaric acid transaminase in vitro and in vivo by U7524 (amino-oxyacetic acid). Biochem. Pharmacol. 5: 323-331.

Watanabe, S., M. Kronski, and O. Creutzfeldt (1966) Postsynaptic potentials in cat's visual cortex following electrical stimulation of afferent pathways. Exp. Brain Res. 1: 272-282. 